\title{
COMPATIBILITY OF THE STATE AID RECOVERY ORDER WITH THE GENERAL PRINCIPLES OF EU LAW
}

\author{
Marek Rzotkiewicz*
}

\begin{abstract}
According to the Article 16.1 of Regulation 2015/1589 the Commission shall not require recovery of the aid if this would be contrary to a general principle of EU law. The potential existence of such a contradiction can be then of un utmost significance to a Member State and aid beneficiaries. However, notwithstanding its significance, the notion of a general principle of EU law has not been defined in the EU legislation, has been derived from the case law of the Court of Justice.

The current paper strives to analyze different sorts of general principles of the EU law and their impact on the recovery obligation, especially as such an obligation differs between particular principles. Some of those principles have no significance at all on the existence of the recovery order, while others can, and sometimes even should, bar the Commission from ordering a Member State to recover an aid.
\end{abstract}

* PhD, legal advisor and lecturer at the Chair of International and European Law at Cardinal Wyszyński University in Warsaw. Any comments are welcome at: m.rzotkiewicz@uksw.edu.pl. 


\section{Introduction}

The Commission shall not require recovery of state aid if this would be contrary to a general principle of EU law. ${ }^{1}$ The general principles of EU law have, therefore, not only an academic dimension but are also capable of directly affecting the existence of the obligation to recover state aid. Should the Commission find the potential recovery of state aid contrary to a general principle of EU law, upon finding the aid incompatible with the internal market, it would abstain from imposing an obligation to recover such aid. The effectiveness principle must, therefore, give precedence to the general principles of EU law (e.g. to the legitimate expectations principle ${ }^{2}$ ) when it comes to enforcing the Commission decisions imposing an obligation to recover state aid.

As an example of a practical application of Article 16.1 of the Procedural Regulation, one can quote the Commission decision in France Télécom:

[T] he Commission has been unable to arrive at a reasonable assessment of the notified measures' 'net' financial impact [...]. Nor does it seem possible to incorporate in the Decision calculation parameters which are sufficiently precise to be able to carry out the final calculation during the Decision's implementing phase. In these particular circumstances, respect for the Member State's rights of defence might constitute an obstacle to recovery pursuant to Article 14(1) of Regulation (EC) No. 659/1999, ${ }^{3}$ according to which 'the Commission shall not require recovery of the aid if this would be contrary to a general principle of Community law.' [...] This conclusion also seems to follow from the principle of legitimate expectation. [...] it follows

1 Article 16.1 of Council Regulation (EU) 2015/1589 of 13 July 2015, laying down detailed rules for the application of Article 108 of the Treaty on the Functioning of the European Union (OJ 2015 L 248/9), hereinafter referred to as the "Procedural Regulation." The Procedural Regulation repealed and replaced Council Regulation (EC) No 659/1999 of 22 March 1999, laying down detailed rules for the application of Article 93 of the EC Treaty (OJ 1999 L 83/1), hereinafter referred to as "regulation 659/1999."

2 Tokai Carbon Co. Ltd, joined cases no T-236/01, T-239/01, T-244/01, T-245/01, T-246/01, T-251/01, and T-252/01, Judgment of 29.4.2004, EU:T:2004:118, at para. 152; Cheil Jedang Corp., Case no T-220/00, Judgment of 9.7.2003, EU:T:2003:193, at para. 33; Kyowa Hakko Kogyo Co., Case no T-223/00, Judgment of 9.7.2003, EU:T:2003:194, at para. 38; Archer Daniels, Case no T-224/00, Judgment of 9.7.2003, EU:T:2003:195, at para. 62.

3 Article 14.1 of the regulation 659/1999 had the same reading as Article 16.1 of the Procedural Regulation. 
Compatibility of the State Aid Recovery Order with the General Principles...

from the case law of the Court of Justice that the Commission is required to take automatically into consideration any exceptional circumstances which justify, in accordance with Article 14(1) of Regulation (EC) No. 659/1999, its refraining from ordering the recovery of unlawfully granted aid where such recovery is contrary to a general principle of Community law, such as respect for the legitimate expectations of the recipients. ${ }^{4}$

Another example can be found in the Commission decision concerning Italian municipal real estate tax exemption, granted to non-commercial entities using real estate for specific purposes:

Since no grounds of compatibility can be identified for the scheme in question, it is found to be incompatible with the internal market. However, in the light of the exceptional circumstances invoked by Italy, recovery of the aid should not be ordered since Italy has demonstrated that it would be absolutely impossible to enforce. ${ }^{5}$

According to Jaros and Ritter, the Commission should have come to this conclusion on its own, ${ }^{6}$ without the parties to the case being forced to make any claims. Sinnaeve is of a similar opinion. ${ }^{7}$ However, should the Commission issue its decision without carrying out the examination of the compatibility with the general principles of an envisaged recovery order, such a decision would be flawed, as it would infringe on Article 16.1 of the Procedural Regulation. This substantiates the filing of the application based on Article 263 TfEU; alternatively, the parties to the case could ask a national court for an application of a preliminary question under Article 267 TfEU in order to examine the validity of the Commission decision.

Such a stance does not find support in practice, however. Neither the Commission, in its decision-making practice, nor EU courts, in their case law, are consistent in their approach to the issue of the general principles of EU law with regard to the Commission recovery decisions It is, therefore, for the applicants to prove the contradiction between the Commission decision ordering the recovery of state aid and the general principles of EU law.

4 C(2004)3060, paras 260-261.

5 C(2012)9461, para. 200.

6 K. Jaros, N. Ritter, Pleading Legitimate Expectations in the Procedure for the Recovery of State Aid - What are the Recent Developments in Case Law and the Commission's Practice? 'EStAL' 2004, no 4.

7 A. Sinnaeve, Procedure Regarding Unlawful Aid [in:] M. Heidenhain (ed.), 'European State Aid Law', C.H.Beck, München 2010, at p. 642. 
Due to a wide range of the general principles of EU law and the risk that the Commission, regardless of its obligation to examine the compatibility of an envisaged recovery order with the general principles of EU law, should fail to carry out such an examination, it is necessary to clarify the notion at issue. It must be pointed out, however, that the potential contradiction between the recovery order and the general principles of EU law should not be confused with the exceptions from the obligation to recover the aid under the Commission decision. The contradiction between the recovery order and the general principles of EU law is (and should be) subject to examination in the course of administrative proceedings prior to issuing a final Commission decision. On the other hand, the exceptions from the obligation to recover the aid refer to situation where the Commission decision has been taken, while the recovery order has not been found contradictory to the general principles of EU law. These are, therefore, two different situations.

\section{The general principles of EU law - notion and function}

Since general principles of law are principles common to a given legal system, the general principles of EU law are the principles common to it. However, a wide recognition of a principle is not sufficient for it to be regarded as a general principle of law; it should also relate to substantial values of a particular field of law or legal system. General principles of law must, therefore, relate to values regarded as important. ${ }^{8}$

The general principles of EU law are a product of the court's case law, ${ }^{9}$ and the court developed a relatively autonomous meaning of that notion. ${ }^{10}$ The relative character of the court's doctrine manifests itself in frequent references to national legal systems or to constitutional traditions which are common to Member States. ${ }^{11}$

8 T. Tridimas, The General Principles of EU Law, Second Edition, Oxford 2006, at p. 1.

9 A. Cieśliński, Wspólnotowe prawo gospodarcze [Community Economic Law], C.H. Beck, Warszawa 2003, at p. 11, C. Mik, Europejskie prawo wspólnotowe. Zagadnienia teorii i praktyki [European Community Law. Theoretical and Practical Problems], vol. 1, C.H. Beck, Warszawa 2000, at p. 486.

10 P. Craig, G. de Búrca, EU Law: Text, Cases and Materials, Sixth Edition, Oxford University Press, 2015.

11 Nold, Case no 4/73, Judgment of 11.1.1977, EU:C:1974:51, at para. 13. 
Compatibility of the State Aid Recovery Order with the General Principles...

According to Mik, the general principles of EU law may be grouped as follows: (i) principles which are inseparably linked to any developed legal system, including general procedural rules, such as the right of defence and principles linked to legal security; (ii) principles that may be derived from national legal systems of Member States and which are common to those states, e.g. the force majeure principle or the right to appeal illegal administrative acts; (iii) principles which derive from the nature of the EU and from its goals, such as the primacy principle, the principle of direct effect, and the solidarity principle, and (iv) human rights, provided that they have EU relevance. ${ }^{12}$

To some extent, a similar division is made by Biernat. He separates the general principles of EU law into two groups. ${ }^{13}$ The first one is composed of principles securing the democratic and law-abiding character of the EU, comprising the principles shown in points (i) and (ii) of Mik's division. The second group is composed of human rights of individuals, which are recognised in the court's case law, as shown in point (iv) of the division proposed by Mik. It appears that Biernat does not include any principles deriving from the nature and goals of the $\mathrm{EU}$ in the general principles of EU law.

Yet another division is proposed by Wróbel, who makes the following distinction: (i) principles on which the constitutional regime of the $\mathrm{EU}$ is built, and which concern the relations between the EU and Member States; (ii) principles which derive from EU law and which refer to relations between EU institutions and Member States, and (iii) principles of substantial EU law, which form the base of EU liberties and policies. ${ }^{14}$

The above seems to suggest that Biernat's division does not count principles deriving from the nature and goals of the EU, which were shown in Mik's proposal, among the general principles of EU law. On the other hand, the typology proposed by Wróbel does not include principles deriving from legal systems of Member States (constitutional traditions that are common to them).

12 C. Mik, Europejskie..., op. cit., at p. 518.

13 S. Biernat, Źródła prawa Unii Europejskiej [The Sources of Law of the European Union] [in:] J. Barcz (ed.) 'Prawo Unii Europejskiej, Zagadnienia systemowe' [Law of the European Union. Systemic questions], PiPG, Warszawa 2003, at p. 185.

14 A. Wróbel, Źródła prawa Unii Europejskiej [The Sources of Law of the European Union] [in:] A. Wróbel (ed.), 'Stosowanie prawa Unii Europejskiej przez sądy' [Application of European Union Law by the Courts], LEX a Wolters Kluwer Business, Warszawa 2010, at p. 49 . 
Despite these differences, it seems that the above typologies generally do not contradict each other. As the division of general principles largely results from subjective assumptions and goals, it seems justified to propose, for the benefit of this examination, the following division: (i) general principles securing the democratic and law-abiding character of the EU, (ii) general principles of the EU which derive from human rights.

One of the main functions of the general principles of EU law is to close any loopholes in the written law and enable EU courts to refer to constitutional traditions of Member States. ${ }^{15}$ Such a reference can be made on the basis of a clear, written provision which provides for such a possibility, or by decision of the court which finds such a reference justified, in order to soften the legal rigorism.

The general principles of EU law are said to enjoy the status of primary law. ${ }^{16}$ This leads to the conclusion that if a Commission decision were found to contradict those principles, it would be legally flawed.

\section{The origin and development of the general principles of EU law}

The first cases in which EU courts made a reference to general principles of law date back to the 1950s. The courts referred to the principles of antidiscrimination, ${ }^{17}$ proportionality, ${ }^{18}$ and direct effect. ${ }^{19}$ In the subsequent years, the court referred to human rights, recognising them as the general principles of the Community law being under protection of the court. ${ }^{20}$ After that, the court found itself obliged to draw inspiration from constitutional traditions common to the Member States. ${ }^{21}$ Finally, it stated that Member States are bound by the ECPHR ${ }^{22}$ and the CFR,

15 T. Tridimas, The General..., op. cit., at p. 17.

16 A. Cieśliński, Wspólnotowe..., op. cit., at p. 11, and C. Mik. Europejskie..., op. cit., at p. 486.

17 Fédération Charbonière Belgique, Case no 8/55, Judgment of 29.11.1956, EU:C:1956:7.

18 Pont-à-Mousson, Case no 14/59, Judgment of 17.12.1959, EU:C:1959:31.

19 Costa/E.N.E.L., Case no 6-64, Judgment of 15.7.1964, EU:C:1964:34.

20 Stauder, Case no 29/69, Judgment of 12.11.1969, EU:C:1969:57, at para. 2.

21 Nold, Case no C 4-73, Judgment of 14.5.1977, EU:C:1974:51, at para. 13.

22 Rutili, Case no 36/75, Judgment of 28.10.1975, EU:C:1975:137, at para. 32. 
Compatibility of the State Aid Recovery Order with the General Principles...

which may have direct effect in the national legal systems of Member States. ${ }^{23}$

The above cases concerned various sectors of the economy, e.g. coal and steel, energy, agriculture, as well as areas of law, such as competition or state aid. In the cases where the court notoriously invoked the general principles of law, the parties to a dispute frequently referred, for example, to the right of defence, ${ }^{24}$ the ownership principle, ${ }^{25}$ the legitimate expectations principle,$^{26}$ or the right to good administration. ${ }^{27}$

However, the analysis of these cases supports the conclusion that, as far as state aid is concerned, the chance to successfully claim the general principles of EU law is much smaller than in other areas of law. As it is generally acknowledged that recovery of aid is not a penalty but rather a logical consequence of finding it unlawful, the ne bis in idem principle has virtually no bearing. ${ }^{28}$ This principle may be claimed only by a Member State which is a party to administrative proceedings before the Commission. ${ }^{29}$ Among the many principles claimed by the parties to a dispute, the most vital are the principles of legitimate expectations, legal certainty, and proportionality.

\section{The general principles of EU law securing democratic and law-abiding character of the EU}

\subsection{Legitimate expectations}

In state aid cases, claims based on legitimate expectations are raised very frequently. This happens either in direct complaints under Article 263 TfEU or as a way of defence before national courts in proceedings concerning the enforcement of Commission decisions. Nevertheless, for a claim based on the legitimate expectations principle to be successful, the claimant

23 F. Fontanelli, The European Union's Charter of Fundamental Rights Two Years Later, Centro Studi Sul Federalismo 2011, vol. 3, no 3, at pp. 22-47.

24 Scott, Case no T-366/00, Judgment of 29.3.2007, EU:T:2007:99.

25 Westdeutsche Landesbank Girozentrale, Cases no T-228/99 and T-233/99, Judgment of 6.3.2003, EU:T:2003:57.

${ }^{26}$ ThyssenKrupp, Case no T-62/08, Judgment of 1.7.2010, EU:T:2010:268.

27 González y Díez, Case no T-25/04, Judgment of 12.9.2007, EU:T:2007:257.

28 B. Brandtner, Recovery and Insolvency - a Case for Greater Flexibility? GCLC Lunch Talk, 24.6.2013.

${ }^{29}$ Ufex, Case no T-613/97, Judgment of 14.12.2000, EU:T:2006:150, at para. 86. 
must prove that they received, from the bodies enforcing or enacting law, assurance that their legal situation will not be subject to an adverse change without a sound justification. ${ }^{30}$ It is not necessary for such an assurance to be addressed directly to the claimant. The interested party may base its claim on a conclusion addressed to another person, if only such a conclusion may, and should, serve as a way of deciding the new case. However, the legitimate expectations principle is a departure from the general rule, and it provides that only due to some exceptional circumstances, ${ }^{31}$ when it is justified by the necessity to protect higher values, is it possible to depart from enforcing the general rules.

According to Rossi-Maccanico, the legitimate expectations principle means that recovery of unlawful state aid is a rule, unless it is contrary to a general principle of EU law. ${ }^{32}$ This principle is not unambiguous, however, as the court's case law does not distinguish between the specific types of events that may justify the rise of legitimate expectations. The court's case law does not make it conditional on the obligation to act within a prescribed time limit, either. ${ }^{33}$ From the perspective of the subject matter of this paper, it is necessary to emphasise that recovery does not concern unlawful aid but rather such aid which is incompatible with the internal market. For the expectation on the part of a beneficiary to be justified, it must, therefore, be based on the assumption that the aid is compatible with the internal market, rather than on the assumption that the aid is lawful. Expectations may also be based on the non-existence of aid. ${ }^{34}$

Legitimate expectations may be pleaded only by the beneficiaries of aid, and not by Member States. Any expectations, falsely raised by national authorities, of which the Commission had not been informed, cannot in any way influence the compatibility of a decision under

30 A. Kobus, Zasada ochrony zaufania w sprawach dotyczacych windykacji pomocy publicznej [The Principle of Protection of Legitimate Expectations in Cases of Recovery of State Aids], Taxpress 2008, no 2, at p. 19.

31 C. Saavedra Pinto, The 'Narrow' Meaning of the Legitimate Expectations Principle in State Aid Law Versus the Foreign Investor's Legitimate Expectations. A Hopeless Clash or an Opportunity for Convergence? 'EStAL' 2016, no 2, at p. 270-285.

32 P. Rossi-Maccanico, The Koninklijke Friesland Foods Case Law: More Legal Certainty in Legitimate Expectation, 'EStAL' 2008, no 1, at p. 112.

33 S. Schønberg, Legitimate Expectations in Administrative Law, Oxford University Press, 2000, at p. 96.

34 A. Giraud, A Study of the Notion of Legitimate Expectations in State Aid Recovery Proceedings: "Abandon All Hope, Ye Who Enter Here”? 'CMLR' 2008, no 5, at p. 1399. 
investigation. ${ }^{35}$ Otherwise, Articles 107 and 108 TfEU would have been deprived of practical significance, for national authorities could rely on their own misconduct or negligence in order to render the Commission decision ineffective.

The position taken by the GC in Ladbroke Racing ${ }^{36}$ and P\&O European Ferries ${ }^{37}$ was even stricter. The court stated that it is not for a Member State but for the beneficiary of aid to claim the exceptional circumstances giving rise to the legitimate expectation that the aid would not be subject to recovery.

The above case law, according to which Member States cannot enjoy legitimate expectations, is unconvincing. It should rather be construed as referring to unlawful aid, in which aid has been granted either without the consent of or against the prohibition of the Commission. ${ }^{38}$ It could also apply to cases giving rise to doubts as to the compatibility of aid with the internal market. In such cases, the blame for granting such aid, at least in the form of negligence, can be attributed to a Member State, for it should have taken into consideration the risk that the Commission may demand the recovery of the aid.

There are doubts, however, concerning cases in which States base their expectations on a Commission's decision-making practice, or on a court's case law. If a State, on the basis of such a decision-making practice ${ }^{39}$ or case law, ${ }^{40}$ finds it unnecessary to notify the Commission of the measures taken, and at a later stage the Commission or the court depart from their practice or case law, the State should be allowed to enjoy legitimate expectations.

35 Fleuren Compost, Case no T-109/01, Judgment of 14.1.2004, EU:T:2004:4, at para. 143.

${ }^{36}$ Ladbroke Racing, Case no T-67/94, Judgment of 27.1.1998, EU:T:1998:7, at para. 183.

37 P\&O European Ferries, Case no T-116/01 and T-118/01, Judgment of 5.8.2003, EU:T:2003:217, at para. 202.

38 90/555/ECSC.

39 In Forum 187, Case no C-217/03, Judgment of 22.06.2006, EU:C:2005:266, at para. 16, the Court stated that in 1984 and 1987 the Commission issued two decisions in which it found that the cases had not contained state aid elements.

40 In Banks, EU:C:2001:456, at para. 77, SIM 2 Multimedia, EU:C:2003:252, at para. 85 , and in SMI, EU:C:2004:238, concerning the liability of third parties for the recovery of state aid, the court consistently held, that this issue must be adjudicated taking into consideration the economic conditions under which the transaction had been effected. 
A similar situation occurs when the Commission finds state aid in a measure under examination for the first time. ${ }^{41}$

In order to effectively invoke legitimate expectations principle, the beneficiary should prove that:

a) they received assurance as to the compatibility of the aid with the internal market (or of a lack of aid in the measure under examination), and the assurance in question was provided by an EU institution;

b) even the most prudent person would not have been able to predict a change that could adversely affect their legal interests;

c) a comparison and weighing of a specific private interest against a public interest give precedence to the private interest.

A person claiming legitimate expectations should prove that they received an assurance from an EU institution. ${ }^{42}$ However, not all EU institutions can be the source of legitimate expectations. ${ }^{43}$ In Forum 187, the court stated that the position of the Council was only a political declaration, and, as such, it did not have legal consequences. ${ }^{44}$ An institution whose position can give rise to legitimate expectations, in most cases, is the Commission, as well as the court. ${ }^{45}$ It is not possible for a beneficiary to claim an assurance received from the state which assured him of the compatibility of the aid with the internal market.

These findings can be criticised with regard to the position of the Council, which is an EU institution. Not all positions of the Council have the character of political declarations, e.g. the Procedural Regulation, which is the most important legal act as regards the recovery of state aid, was issued by the Council. Even if it is justified to say that decisions issued by the Council under Article 108.2 TfEU cannot give rise to legitimate expectations, ${ }^{46}$ the general exclusion of such a possibility does not seem justified.

$41 \quad C(2004) 3060$.

42 Mehibas Dordtselaan, Case no T-290/97, Judgment of 18.1.2000, EU:T:2000:8, at para. 59, and Judgment P\&O European Ferries, supra, at para. 202.

${ }_{43}$ D. Grespan, Recovery of Unlawful and Incompatible Aid [in:] W. Mederer, N. Pesaresi, M. van Hoof (eds) 'EU Competition Law, Volume IV: State Aid, Book One', Claeys \& Casteels, 2008, at pp. 671-680.

44 Judgment Forum 187, supra, at para. 151.

45 A. Kobus, Zasada ochrony..., op.cit., at p. 19.

${ }^{46}$ This decision is taken as an exception from the rules of state aid, and as such should not constitute the basis of legitimate expectations in ordinary situations. 
Compatibility of the State Aid Recovery Order with the General Principles...

An assurance from an EU institution can take the form of a positive action ${ }^{47}$ or inaction. In Rijn-Schelde Verolme (RSV), the court stated that a Commission's delay of 26 months in making the contested decision could establish a legitimate expectation on the applicant's part, especially as the issue was not complex. ${ }^{48}$ However, in Fleuren Compost, the court found that the lapse of five years could not be regarded as an unreasonable delay. ${ }^{49}$

The next premise for an effective claim of legitimate expectations is that a prudent beneficiary, even with utmost care, could not have envisaged that an EU institution would take a measure adversely affecting its legal situation. ${ }^{50}$ Legitimate expectations cannot be claimed by beneficiaries who failed to check whether all formal requirements for aid have been met. ${ }^{51}$ Such beneficiaries have not verified (by demanding that a State notify the Commission of its plans to grant aid) if such aid was compatible with the internal market. Since only the Commission may examine the compatibility of aid, and the compatibility of aid was not confirmed by the Commission, neither the State nor the beneficiary can exclude that the aid can be found to be incompatible with the internal market. In such a situation, not only has the beneficiary failed to exercise its utmost care, but it has not displayed any.

This remains an ambiguous issue, as the court found such a possibility in $R S V$, irrespective of the fact that the case concerned unlawful aid which was granted without the consent of the Commission. Giraud, as well, points out that in exceptional circumstances the beneficiary of unlawful aid can successfully claim their legitimate expectation that the measure under examination does not constitute state aid. ${ }^{52}$

The above findings, save for the statement made by Giraud, who referred to the non-existence of aid, do not seem convincing. Even though the court has found such a possibility in RSV, as well as in Commission/

47 In Forum 187, supra, at para. 368, AG Léger stated that there must be an act or conduct on the part of the Community administration capable of giving rise to such an expectation.

48 RSV, Case no 223/85, Judgment of 24.11.1987, EU:C:1987:502, at para. 17.

49 Fleuren Compost, Case no T-109/01, Judgment of 14.01.2004, EU:T:2004:4, at paras 147-148.

50 Johann Lührs, Case no 78/77, Judgment of 1.2.1978, EU:C:1978:20; Van den Bergh, Case no 265/85, Judgment of 11.3.1987, EU:C:1987:121.

51 Opinion in Commission/Germany, Case no C-5/89, EU:C:1990:187, at para. 24.

52 A. Giraud, A study of..., op. cit., at p. 1399. 
Germany, it does not constitute a strong argument. The possibility to revert to legitimate expectations is an exception from a general rule and, as such, should not be construed expansively. Furthermore, an exception cannot form a basis for a new principle. Therefore, the court's finding, in which it allowed beneficiaries of unlawful aid to claim legitimate expectations, does not seem justified.

Restricting the possibility of beneficiaries of unlawful aid relying on legitimate expectations to truly exceptional circumstances is more convincing. The mere fact that applicants are small undertakings does not justify a legitimate expectation on their part as to the compatibility of aid, when they have failed to ensure that the procedure laid down by Article 108(3) of the Treaty has been observed. ${ }^{53}$ Similarly, beneficiaries' claims to the effect that they have not known that the aid has been granted without the Commission's consent, that the Commission should have been notified, or that they have been misled by state bodies in these matters, do not justify legitimate expectations. In such cases, the beneficiaries may claim compensation from the State, provided that their national law allows for such a possibility. In a dispute before a national court, the court has the power - if necessary, after presenting the court questions under Article 267 TfEU - to resolve whether the beneficiary's legitimate expectations are justified. ${ }^{54}$ However, the opportunity to claim compensation does not relieve the beneficiary from its obligation to repay the aid. What is more, if the beneficiary could have brought an action against the Commission decision but failed to do so, it is barred from claiming invalidity of this decision before a national court. ${ }^{55}$

Legitimate expectations are not justified by the circumstance that the aid did not have to be notified under Article 108 TfEU, (e.g. de minimis), if it was misused.$^{56}$ However, if the defect of the aid is of a substantial rather than of a procedural - character, such a clear-cut position does not seem to be fully justified. Consequently, the EU courts should not dismiss legitimate expectations prior to examining the case. The same applies

53 Alzetta Mauro, Joint Cases no T-298/97, T-312/97, T-313/97, T-315/97, T-600/97 to T-607/97, T-1/98, T-3/98 to T-6/98, and T-23/98, Judgment of 15.6.2000, EU:T:2000:151, at para. 172 .

54 Commission v. Germany, Case no C-5/89, Judgment of 20.9.1990, EU:C:1990:320, at para. 16.

55 TWD Deggendorf, Joint Cases no T-244/93 and T-486/93, Judgment of 13.9.1995, EU:T:1995:160.

56 C(2002) 4359. 
to the cases where the State acted in an unusual manner, and it was not evident whether the measure contained aid. In the latter example, it is possible, however, to state that a careful and prudent entrepreneur would have asked the State authorities to notify the Commission of the measure in order to acquire legal certainty. A failure to submit such a request results in the possibility of claiming legitimate expectations being lost.

The last prerequisite for claiming legitimate expectations is that the applicant must be able to prove that the result of a comparison between the public interest in the recovery of the aid and the private interest in keeping it, is favourable to the beneficiary opposing the recovery. ${ }^{57}$ It remains unclear, however, how such a test should be made, ${ }^{58}$ so it is necessary to examine the court's case law.

As stated by the court in CNTA, the comparison of the aforementioned interests does not have to show that private interest prevails over the public interest. ${ }^{59}$ In this case, as confirmed in the subsequent case law, ${ }^{60}$ the court found that, in the absence of an overriding public interest, it is necessary to protect legitimate expectations. It is, then, for an EU institution to prove the existence of an overriding public interest in excluding protection based on legitimate expectations.

Answering the question of whose responsibility it is to make the comparison does not, however, clarify how it is to be executed nor does it specify the circumstances that are to be taken into consideration. Some guidelines on this matter can be found in the court's case law, e.g. the order in Technische Glaswerke. ${ }^{61}$ In this order, concerning an application for interim measures, the court found that it was necessary to examine the circumstances of the case:

[I]n view of the very particular circumstances of the present case, in particular the very low amount of the aid in question as compared with the total amount of aid granted to the applicant, it is unrealistic to consider that, if the applicant had to repay the aid immediately, it would be able to regain its previous specific competitive position

57 Affish BV, Case no C-183/95, Judgment of 17.7.1997, EU:C:1997:373, at para. 57.

58 A. Giraud, A study of..., op. cit., at p. 1399.

59 CNTA, Case no 74/74, Judgment of 15.6.1976, EU:C:1976:84, at para. 44.

60 Ditta Angelo Tomadini, Case no 84/78, Judgment of 16.5.1979, EU:C:1979:129, at para. 20; Sofrimport, Case no 152/88, Judgment of 17.1.1992, EU:C:1992:21, at paras 16 and 19.

61 Technische Glaswerke, Case no T-198/01 R [III], Order of 12.5.2004, EU:T:2004:147, at paras $64-65$. 
on the glass market or markets in question. Nor can those arguments call into question the fact that Schott Glas's turnover, which is considerably higher than that of the applicant, precludes it from suffering a substantial loss as a result of the grant of interim measures. Moreover [...] it remains unlikely in any event that TGI will be in a position to act in a way which distorts competition and is liable to affect either Schott Glas or TGI's other competitors.

65. Finally, in the specific context of the present order, account must be taken of the fact that delivery of the judgment in the main action is now imminent. Consequently, even if suspension of the operation of the contested decision could, by maintaining TGI's presence on the glass market or markets in question, lead to distortion of competition or have an adverse effect on other interests at stake, those effects would now be produced for only a very limited period.

Even though the above case did not concern resignation from issuing a recovery order, but only the imposition of interim measures, the guidelines given have general significance. It is necessary, then, in making a comparison of two conflicting interests, to consider such details of the case under scrutiny as the amount of aid to be recovered, the size of the beneficiary, and its position on the market, as well as the size and position of its competitors, the impact that the aid can have on market, and the duration of any distortion caused by the aid. Furthermore, one cannot exclude the relevance of other circumstances, as the case may be.

\subsection{Legal certainty principle}

Legal certainty is a general principle in democratic legal systems. It states that a person can trust that their rights will not be violated without a sound reason. ${ }^{62}$ A claim based on legal certainty is often raised along with a claim based on legitimate expectations; however, very rarely is there a clear distinction between the two. Thus, it remains unclear whether these are two separate principles, or if the applicants form two separate claims on the basis of a single principle.

62 K. Saryusz-Wolska, M. Kośka, W poszukiwaniu utraconej skuteczności. Zasada natychmiastowego i skutecznego zwrotu pomocy państwa [Seeking the Lost Effectiveness. Principle of Prompt and Effective Recovery of State Aid] [in:] B. Kurcz (ed.), 'Prawo i ekonomia konkurencji, Wybrane zagadnienia' [Law and Economy of the Competition, Selected Issues], LEX a Wolters Kluwer Business, Warszawa 2010, at p. 401. 
Compatibility of the State Aid Recovery Order with the General Principles...

A definitive answer can be found neither in the legal doctrine ${ }^{63}$ nor in the court's case law, both of which are inconsistent, sometimes referring to these principles separately and sometimes jointly. ${ }^{64} \mathrm{~A}$ breakthrough appears to have been made in Salzgitter, where the GC distinguished between the two principles:

However, the applicant is not pleading a legitimate expectation that aid was properly granted but rather a breach of the principle of legal certainty, a matter which does not depend solely on the conditions required for the creation of a legitimate expectation on the part of the recipient of the aid. ${ }^{65}$

The GC has not only distinguished between these two principles but also pointed out that, with regard to legal certainty, requirements have to be more restrictive.

Only time can tell whether the above judgment is to give rise to a new line of case law; however, this issue is yet to be settled in the Commission's decision-making practice. In G.I.E. fiscaux, the Commission found that:

The Commission considers, therefore, that France need not recover any incompatible aid unlawfully granted since the entry into force, in 1998, of Law No. 98-546 as part of financing operations concerning which the competent national authorities have undertaken to grant

63 Cf. D. Grespan, A. Pelin, L. Rossi, Recovery of Unlawful and Incompatible Aid [in:] N. Pesaresi, K. Van de Casteele, L. Flynn, Ch. Siaterli (eds), 'EU Competition Law', Volume IV: State Aid, Book Two, Second Edition, Claeys \& Casteels, 2016, at p. 1556, where the authors make a distinction between these principles by stating that, although in the Court's case law they are treated jointly, there are differences between them, and the legal certainty principle is less restrictive. Also K. Saryusz-Wolska, M. Kośka, W poszukiwaniu..., op. cit., at p. 401, treat these principles separately, even though they do not point to specific differences. Similarly, A. Sinnaeve, Procedure Regarding..., op. cit., at pp. 642-647. This author, however, notes that it is extremely rare for the legal certainty principle to be effective in state aid matters. Lastly, in European State Aid Law and Policy, Third Edition, Oxford-Portland (Oregon) 2015, at p. 601, C. Quigley appears to link the legal certainty principle with the prescription period, which he does not apply to the legitimate expectations principle.

64 Openbaar Ministerie, Case no 21/81, Judgment of 10.2.1982, EU:C:1982:47; GruSa Fleisch, Case no C-34/92, Judgment of 15.7.1993, EU:C:1993:317; Pokrzeptowicz-Meyer, Case no C-162/00, Judgment of 29.1.2002, EU:C:2002:57; Elektrownia Pątnów II, Case no C-441/08, Judgment 12.11.2009, EU:C:2009:698.

65 Salzgitter AG, Case no T-308/00, Judgment of 1.7.2004, EU:T:2004:199, at para. 166. 
the benefit of the scheme provided for in Article 39 CA of the General Tax Code by a legally binding act (98) predating the publication in the Official Journal of the European Union, on 13 April 2005, of the Commission's decision of 14 December 2004 to initiate the formal investigation procedure under Article 88(2) of the Treaty. ${ }^{66}$

However, more decisions are needed if this line of reasoning is to be confirmed. The Commission has, nonetheless, stated that the judgment on whether a beneficiary can claim legal certainty may be based on the information that an investigation has been opened, featuring its date.

\subsection{Proportionality principle}

While objecting decisions in which the Commission orders a Member State to recover aid, beneficiaries sometimes claim the proportionality principle. ${ }^{67}$ These claims are based on a presumption that the Commission should have abstained from imposing an obligation to recover the aid, taking a less drastic measure, instead. Such claims are consistently dismissed by EU courts, reasoning that the obligation to recover aid is a logical consequence of finding it unlawful. ${ }^{68}$ As a result, the recovery of aid aiming to restore the previously existing (before the aid was granted) situation cannot be regarded as disproportionate. ${ }^{69}$

Basing the recovery obligation on logic is unjustified. If it were really based on logic, then, after finding the aid incompatible, the Commission would always have to issue an order to recover such aid. ${ }^{70}$ There would be no escape from that conclusion, even if it were contrary to the general

${ }_{66} \mathrm{C}(2006) 6629$, at para. 194.

${ }_{67}$ Judgment TWD Deggendorf, supra; Friuli-Venezia Giulia, Case no T-288/97, Judgment of 4.4.2001, EU:T:2001:115; Kahla/Thüringen, Case no T-20/03, Judgment of 24.9.2008, EU:T:2008:395.

68 Tubemeuse, Case no 142/87, Judgment of 21.3.1990, EU:C:1990:125, at para. 66; Siemens, Case no T-459/93, Judgment of 8.6.1995, EU:T:1995:100, at para. 96; Spain/ Commission, Case no C-169/95, Judgment of 14.1.1997, EU:C:1997:10, at para. 47; Alzetta Mauro and others, Case no T-298/97, Judgment of 15.6.2000, EU:T:2000:151, at para. 169.

69 A. Sinnaeve, State Aid Control: Objectives and Procedures [in:] S. Bilal, P. Nicolaides (eds), 'Understanding State Aid Policy in the European Community. Perspectives on Rules and Practice', Kluwer Law International, 1999, at p. 21.

70 M. Rzotkiewicz, The General Principles of EU Law and Their Role in the Review of State Aid Put into Effect by Member States, 'EStAL' 2013, no 3, at pp. 464-477. 
Compatibility of the State Aid Recovery Order with the General Principles...

principles of EU law. The mere existence of such exceptions would be illogical. Furthermore, the opportunity to revert to the general principles of law (also EU law) is not based on logic but rather on values commonly regarded as important. ${ }^{71}$

The above attitude should be examined critically. The proportionality principle refers to all fields of EU law, as confirmed by the Protocol on the Application of the Principles of Subsidiarity and Proportionality. State aid law is no exception here. The proportionality principle also refers to all kinds of actions by EU institutions. Therefore, while abstaining from deciding whether, in a particular situation, a recovery order would be contrary to the proportionality principle, the author of this paper submits that the proportionality principle should not be rejected by EU courts and the Commission.

\subsection{Subsidiarity principle}

The principle of subsidiarity is not only a general principle of EU law but also a political principle. ${ }^{72}$ Article 5.3 TEU stipulates that in areas which do not fall within its exclusive competence, the European Union shall act only if and in so far as the objectives of the proposed action cannot be sufficiently achieved by Member States, either at the central level or at the regional or local level, but can, by reason of the scale or effects of the proposed action, be better achieved at the EU level. The institutions of the European Union shall apply the principle of subsidiarity, as laid down in the Protocol on the Application of the Principles of Subsidiarity and Proportionality.

The above Article sets forth the subjective scope of the subsidiarity principle (i.e. the matters which do not fall within the exclusive competence of the EU), and the condition which must be met for the EU to act (the higher efficiency). Unlike the proportionality principle, the subsidiarity principle refers exclusively to law-making procedures, and, what is more, only to legislative acts. ${ }^{73}$

71 T. Tridimas, The General..., op. cit., at p. 1.

72 C. Mik, Parlamenty narodowe wobec zasady pomocniczości w świetle prawa i praktyki Unii Europejskiej [National Parliaments and the Principle of Subsidiarity in the Light of Law and Practice], Wydawnictwo Sejmowe, Warszawa 2015, at p. 11.

73 Ibid., at pp. 40-41. 
Any actions taken by the European Union (i.e. its institutions) in the areas where the EU has no competences, or outside its exclusive competences where the objectives of the proposed action can be sufficiently achieved by Member States, are ultra vires. ${ }^{74}$

This leads to the question if the subsidiarity principle applies to matters concerning the state aid recovery. Particularly important is the answer to the question of who should issue the recovery order, the Commission or a Member State. If it is the former, should the recovery order be preceded with the analysis of its compatibility with the subsidiarity principle?

With regard to the above doubts, it must be noted that the Commission recovery decisions are acts similar to the national administrative ones. They are not legislative acts, and the subsidiarity principle does not apply to them. ${ }^{75}$ Moreover, for a recovery order to be issued, the aid has to be found incompatible with the internal market. Finding the aid unlawful (not approved by the Commission) is not enough, and only the Commission has the competence to examine the compatibility of aid with the internal market.

This applies to misused aid; although, in that instance, there are more doubts. Under Article 1(g) of the Procedural Regulation, misused aid means aid used by the beneficiary in contravention of a decision taken pursuant to Article 4.3, 7.3, or 4 of Regulation 659/1999 or Article 4.3, 9.3, or 4 of the Procedural Regulation. The fault of such aid derives not from the aid granting but from its using. The aid has been used by a beneficiary in breach of a decision not to raise objections, a positive decision, or a conditional decision. ${ }^{76}$

Finding such a breach, contrary to finding the incompatibility of aid, does not fall into the exclusive remit of the Commission; consequently, it may seem justified to say that the subsidiarity principle applies to recovery decisions, at least with regard to misused aid, and the Commission should analyse the compatibility between a potential recovery order and the subsidiarity principle. This reasoning, however, ignores the fact that the mere finding that aid has been misused is not sufficient for issuing a recovery

74 P. Craig, The ECJ and Ultra Vires Action: A Conceptual Analysis, 'CMLR' 2011, no 2, at p. 395.

75 Mitteldeutsche Flughafen, Case no C-288/11 P, Judgment of 19.12.2012, EU:C:2012:821, at para. 79.

${ }^{76}$ Mory, Case no C-33/14 P, Opinion of AG Paolo Mengozzi, EU:C:2015:409, at para. 140 . 
Compatibility of the State Aid Recovery Order with the General Principles...

order. The Commission also has to find the aid incompatible with the internal market, in light of the goal for which the aid has eventually been used. What is more, even the aid which has been found incompatible with the internal market, when used for a particular goal, does not have to be incompatible with regard to a different goal. This, again, leads to the conclusion that the subsidiarity principle does not apply to recovery decisions.

Notwithstanding the above considerations, the subsidiarity principle does not apply to recovery decisions due to other reasons. The Commission issues recovery decisions only if a Member State has not recovered the aid on its own. EU law does not pose an obstacle to recovering aid without a Commission decision; on the contrary, it encourages Member States to do so for the sake of the effectiveness of EU law. This is particularly true since, prior to issuing a recovery decision, the Commission has to undergo lengthy and cumbersome proceedings during which a Member State usually voices its objects. Recovery decisions are typically issued by the Commission after many years, in which time the Member State could have recovered the aid on its own, should it have wished to. Instead, Member States usually challenge Commission decisions before EU courts, prolonging the proceedings. A lack of intervention on the part of the Commission would not only have failed to improve the timeliness of the recovery, but it could have resulted in the aid not being recovered at all. Thus, the exclusive competence of the Commission to analyse the aid compatibility and the fact that the recovery decisions issued by the Commission are not legislative acts are not the only obstacles in the way of applying the subsidiarity principle to recovery cases. Without the Commission's involvement, restoring the market situation from before the aid was granted will not be achieved because Member States largely oppose the recovery of the aid.

\subsection{Lapse of the prescription period}

The possibility of initiating legal proceedings without any limitation in time may be regarded as a violation of the legal certainty principle ${ }^{77}$ and is contrary to the general principles of EU law. A claim based on the

77 J. Raitio, The Principle of Legal Certainty as a General Principle of EU Law [in:] U. Bernitz, J. Nergelius, C. Cardner, X. Groussot (eds), 'General Principles of EC Law in a Process of Development: Reports from a Conference in Stockholm, Stockholm, 23-24 March 2007', Kluwer Law International, 2008, at p. 47. 
lapse of the prescription period was raised in the BFM case. ${ }^{78}$ Since, prior to 1999 , there had been no provisions specifying the prescription period as regards state aid law, the applicants invoked provisions from other areas of law, using analogy. The GC dismissed the claim at issue, pointing out that state aid law featured no provisions concerning the prescription period in relation to the recovery order, whereas legal certainty demands that the prescription period be specified in advance, using legislative measures.

On the other hand, in the Salzgitter case, the GC found that the Commission violated the legal certainty principle, due to the fact that it had been aware, for nearly a decade, that the beneficiary received aid before eventually ordering the Member State to recover the aid in $1998 .^{79}$ That judgment was subsequently set aside by the court, which stated that it was necessary to consider the strict nature of the state aid regime under the ECSC Treaty. In cases where aid has been granted under the ECSC Treaty without appropriate notifications being made, a delay by the Commission in exercising its supervisory powers and ordering recovery of the aid does not render that recovery decision unlawful, unless the Commission manifestly failed to act and clearly breached its duty of care. The court, however, also stated that even in a situation where the Community legislature has not expressly indicated any prescription period, the Commission cannot indefinitely delay the exercise of its power. ${ }^{80}$

This changed slightly when Regulation 659/1999 came into force. Under its Article 15, superseded by the current Article 17 of the Procedural Regulation, the Commission's competence with regard to the recovery of unlawful aid has been limited by a 10 -year prescription period, starting from the granting of unlawful aid. Any action taken by the Commission or by a Member State with regard to such aid interrupts and resets the prescription period. ${ }^{81}$

The aforementioned change raises some doubts. Article 17 of the Procedural Regulation stipulates that the prescription period begins to run on the granting of unlawful aid; however, it is largely the incompatible and misused - rather than unlawful - aid that needs to be recovered. If

${ }^{78}$ BFM, Cases no T-126/96 and T-127/96, Judgment of 15.9.1998, EU:T:1998:207, at para. 61.

79 Judgment Salzgitter, supra, at paras 179-182.

80 Judgment Salzgitter, supra, at para. 103.

81 R. Barents, Directory of EC Case Law on State Aids, Kluwer Law International, 2008, at p. 547. 
Article 17 of the Procedural Regulation really refers to unlawful aid, as its wording implies, then EU law is more lenient with respect to cases where aid has been granted unlawfully (without the consent of the Commission or against its prohibition) than in cases where all requirements have been met. In the latter cases, all the rules concerning the granting of aid were observed by Member States, which have obtained the Commission's approval before granting aid only to find the aid incompatible with the internal market upon re-examination or following a change of circumstances. ${ }^{82}$ Thus, incompatible aid which is not unlawful (e.g. existing aid which, due to some legal changes, was found to be incompatible with the internal market) would be treated more severely than unlawful aid. Such an interpretation cannot be permitted, as it would lead to the conclusion that while the recovery of unlawful aid is limited by a 10 -year prescription period, the recovery of incompatible aid, which is not unlawful, remains unlimited in time. As the court found in the ACF Chemiofarma, ICI, and BFM cases, ${ }^{83}$ the legal certainty principle demands that the prescription period be set in advance, using legislative measures.

Nevertheless, Article 15.2 of Regulation 659/1999 and Article 17.2 of the Procedural Regulation refer only to unlawful aid. Although in Salzgitter the court found that even in a situation where the Community legislature has not expressly laid down any prescription period, the Commission cannot indefinitely delay the exercise of its power, it has not been confirmed in later judgments. More importantly, however, if state aid has been granted under the ECSC Treaty, the beneficiary must prove that the Commission has manifestly failed to act and clearly breached its duty of care in the exercise of its supervisory powers.

The rule that the prescription period begins to run on the date of granting the aid and may be interrupted and reset, is another source of doubt. It allows the Commission to order the recovery of aid granted virtually at any point in the past. Prior to Regulation 659/1999 coming into force, it had not been possible to claim the lapse of the prescription period, as there had been no rules stipulating it. At present, the regulation formally provides for such

${ }^{82}$ This can be the case if the previously approved aid (e.g. granted as part of an aid scheme) was found to be incompatible with the internal market, due to some legal changes, and the Member State refused to comply with the Commission's proposal as to the change of such aid.

83 ACF Chemiefarma, Case no 41/69, Judgment of 15.7.1970, EU:C:1970:71, at paras 19-20; ICI, Case no 48/69, Judgment of 14.7.1972, EU:C:1972:70, at paras 47-48; Judgment BFM, supra, at para. 67. 
a possibility; nevertheless, the Commission can, by its own activity, interrupt and reset the prescription period, prolonging it indefinitely. The Commission does not have to meet specific requirements to effectively interrupt the prescription period. It is sufficient for the Commission to send a question to a Member State. It is not even necessary for such a question to take any particular form (e.g. that of a decision) and it can be sent via e-mail. The simple form of the request to provide information does not deprive it of its legal effects as regards the interruption of the prescription period.

Though the GC has found in Département du Loiret that the Commission can order recovery of aid only if the aid was under its scrutiny at the date Regulation 659/1999 came into force, ${ }^{84}$ the judgment does not hold much weight. Even now, the Commission can still issue a recovery order with respect to aid granted on 23.7.1952; it would merely have to prove that the aid was under its scrutiny at the date Regulation 659/1999 came into force and that the Commission has interrupted the prescription period.

As the currently binding provision stipulates a 10-year prescription period, which may be interrupted and reset, the prescription period can be effectively claimed only as an exception, if at all. This is especially true as, for the interruption of a prescription period, it is sufficient that the Commission sends an e-mail with questions. Such an e-mail does not have to be sent to a beneficiary, who, after all, is not a party to the proceedings, ${ }^{85}$ and it is enough if a message is sent to a Member State, which has no obligation to inform the beneficiary. The beneficiary may not even be aware that the Commission has taken any measures that could affect their legal position.

\subsection{Res iudicata}

The res iudicata, found to be a general principle of EU law, ${ }^{86}$ has a long legal tradition; it originates from Roman law, where it was expressed in the form of exceptio rei iudicatae. ${ }^{87}$ By invoking res iudicata, the applicant

${ }^{84}$ Département du Loiret, Case no T-369/00, Judgment of 10.4.2003, EU:T:2007:100, at para. 50.

85 Scott, Case no C-276/03 P, Judgment of 5.10.2006, EU:C:2006:651, at para. 33.

${ }^{86}$ Eco Swiss China Time, Case no C-126/97, Judgment of 1.7.1999, EU:C:1999:269, at para. 46.

${ }_{87}$ J. Kamiński, W. Rozwadowski, W. Wołodkiewicz, Prawo Rzymskie - Słownik encyklopedyczny [Roman Law - Encyclopaedic Dictionary], Wiedza Powszechna, Warszawa 1986. 
Compatibility of the State Aid Recovery Order with the General Principles...

claims that the legal proceedings at issue have been concluded with a final and binding judgment. In Köbler, the court stated that, in order to ensure the stability of the law and legal relations, on the one hand, and the sound administration of justice on the other, it is important that judicial decisions which have become final, upon all possibilities of appeal being exhausted or following the lapse of all relevant time limits, can no longer be called in question. ${ }^{88}$

The significance of this principle manifests itself in that the Commission should take it into account on its own if the case has been legally adjudged ${ }^{89}$ and if it may resolve the case. There is no need for a party to the proceedings to raise any claim in such a case.

If, in the case under examination, res iudicata originated from a judgment rendered by an EU court, the Commission should abstain from examining the compatibility of aid with the internal market. Such an examination would be inadmissible. On the other hand, if res iudicata originated from a final judgment of a national court, the Commission could review the case. However, it should decide whether the recovery of aid does not contradict a general principle of EU law (Article 16 of the Procedural Regulation).

The distinction, depending on which court made a judgment, has its justification in the fact that their scope of jurisdiction differs. National courts have no power to adjudicate compatibility of state aid with the internal market..$^{90}$ Although the same is true for EU courts, they may decide if the formal investigation procedure carried out by the Commission was run properly. National courts have no power to conduct such an examination, and they may only verify whether the formal requirements for granting the aid have been met. ${ }^{91} \mathrm{~A}$ failure to take notice of the above may lead to the conclusion that res iudicata could protect such judgments of national courts that were given outside the jurisdiction of these courts. On the other hand, EU courts or the Commission could disregard res iudicata resulting from

88 Köbler, Case no C-224/01, Judgment of 30.9.2003, EU:C:2003:513, at para. 38.

89 Hoogovens Groep, Cases no $172 / 83$ and 226/83, Judgment of 19.9.1985, EU:C:1985:355, at para. 9; France/EU Parliament, Cases no 358/85 and 51/86, Judgment of 22.9.1988, EU:C:1988:431, at para. 12; Judgment P\&O European Ferries, supra, at para. 77.

90 Steinike \& Weinlig, Case no C-78/76, Judgment of 22.3.1977, EU:C:1977:52, at para. 14.

91 SFEI, Case no C-39/94, Judgment of 11.7.1996, EU:C:1996:285, at para. 49; FNCE, Case no C-354/90, Judgment of 21.11.1991, EU:C:1991:440, at para. 10; Transalpine Ölleitung, Case no C-368/04, Judgment of 5.10.2006, EU:C:2006:644, at para. 39. 
national courts judgments, even if such judgments were given within the jurisdiction of the courts. Thus, it is hard to accept the position expressed in Fallimento Olimpiclub, where AG Màzak seemed to question the exceptional status of the possibility to deny national court's judgments res iudicata. ${ }^{92}$

The possibility to disregard the judgments of national courts res iudicata should be limited only to cases in which national courts have given such judgments with a breach of the exclusive jurisdiction of the Commission or EU courts. By accepting the position expressed by AG Màzak, one would arrive at the conclusion that, from the EU perspective, final judgments given by national courts have no significance.

The position expressed by AG Màzak, based on uncritical attachment to the effectiveness principle, is all the more unconvincing as it unreservedly presupposes the superiority of one principle over another without providing any reasons. Such a way of reasoning may also lead to a law contrary to the general principles of EU law being passed. Therefore, only if the decision issued by the Commission is compatible with the general principles of EU law may the Commission order the recovery of state aid; otherwise, the Commission should abstain, under Article 16.1 of the Procedural Regulation, from issuing the order. In such a case, the Commission should limit itself to finding the aid incompatible with the internal market. Such a conclusion of the case would not deprive the beneficiary's competitors of legal protection, as they would be free to seek compensation from a Member State. The practical application of res iudicata by EU courts with respect to state aid cases was exemplified in Lucchini ${ }^{93}$ and Frucona Košice. ${ }^{94}$

The first of these cases concerned a question posed by an Italian court, enquiring whether EU law excludes the application of a national provision setting out the res iudicata principle, when the application of that principle makes it impossible to recover the aid which was found incompatible with the internal market in the final decision of the Commission. The answer given by the court was in the affirmative.

However, it is not the answer itself that is the most interesting aspect of this case but rather the court's reasoning, as it referred to the jurisdiction of national courts. The court emphasised that national courts have no power to examine the compatibility of state aid with EU law, which falls

${ }^{92}$ Fallimento Olimpiclub, Case no C-2/08, Opinion of AG Màzak, EU:C:2009:180, at para. 61.

${ }_{93}$ Lucchini, Case no C-119/05, Judgment of 18.7.2007, EU:C:2007:434.

${ }^{94}$ Frucona Košice, Case no C-507/08, Judgment of 22.12.2010, EU:C:2010:802. 
under the exclusive competence of the Commission. ${ }^{95}$ The court noted that, in the case at issue, national courts' judgments had been given in breach of the Commission's exclusive competence to examine state aid's compatibility with the internal market. Notwithstanding the fact that in 1990 the Commission found the aid to be incompatible with the internal market and banned Italy from granting it, a year later, the Italian courts ordered the payment of the aid, not only trespassing on an area reserved for the exclusive jurisdiction of the Commission but also ordering the payment of aid in breach of a final and binding decision of the Commission forbidding that. It is, then, possible to state that the Italian courts ordered national administrative bodies to disrespect the Commission decision. Looking at the Lucchini case from this perspective, it seems that the judgment is significant for national court's judgments, given outside of the field of national courts' jurisdiction and within the sole jurisdiction of $\mathrm{EU}$ institutions. If, however, national courts had respected the limits of their own and EU institutions' jurisdiction, it appears that the decision made by the court should have been different.

This is confirmed by the court's direct reference to jurisdiction enjoyed by national courts and the Commission. AG Geelhoed, in its opinion, also expressly referred to the res iudicata principle and the infringement by the Italian national courts of their jurisdiction:

In the present case, however, the final judgment of the Corte d'appello not only has consequences for legal relations under Italian law between the subsidised party and the Italian State: it also sets aside the Commission's exclusive power, which is governed by Community law, to examine the aid measure in question for its compatibility with the common market and impinges on the obligations to which Italy is subject under Community law when granting State aid. ${ }^{96}$

Having in mind the above explanations and the court's judgment, which in extenso refers to the violation by Italian courts of the Commission jurisdiction, it seems that it was this aspect, as well as the fact that the Italian courts rendered their judgments only after the Commission had issued its decision, that was decisive in the Lucchini case. This was confirmed by AG Villalón in the Frucona Košice case:

95 Judgment Lucchini, supra, at paras 50-54.

96 Lucchini, supra, Opinion of the AG Geelhoed, at para. 47. 
In the context of those proceedings, procedurally national but functionally and substantively Community proceedings, it was, therefore, possible for a judgment to be given which, from the point of view of national law, was without doubt final but which, in the context of the, substantively speaking, Community proceedings, was deprived of all legal effect. In that case and in a case like it, therefore, the Court always has the last (definitive and final) word. ${ }^{97}$

This, in itself, does not mean that EU courts do not respect res iudicata resulting from national courts' judgments. It would rather appear that only national court judgments which breach the jurisdiction of EU institutions do not enjoy res iudicata in EU law. Thus, it is questionable to say that the Lucchini case concerned the collision of two values: effectiveness and the res iudicata principles. ${ }^{98}$ In this case, the judgments of national courts were given outside their jurisdiction, so those judgments could have not enjoyed the status of res iudicata. One could even go as far as to say that those judgments, in the field in which they were given, were issued by unauthorised bodies.

The above mentioned Frucona Košice case is quite different. In that case, the Commission charged the Slovak Republic with the non-enforcement of its decision on state aid to Frucona Košice. The non-enforcement of that decision was indisputable. However, the case concerned an arrangement with creditors under a bankruptcy procedure, which was approved by national court in 2004 and acquired the force of res iudicata. Later, in 2006, the Commission found that the arrangement constituted state aid and ordered the Slovak Republic to recover it.

Frucona Košice differed from Lucchini, where national courts rendered their judgments after the Commission had found the aid incompatible with the internal market and had forbidden granting it. In Frucona Košice it was the other way around, the judgment of the national court preceded the Commission's decision. Consequently, a question arose if final and binding judgments of national courts can justify non-enforcement of the Commission decision ordering recovery of aid.

The Commission opposed that notion and stated that it was necessary to misapply any national rule that could hinder the enforcement

97 Frucona Košice, infra, Opinion of the AG Villalón, at para. 49.

98 M. Baran, Glosa do wyroku TS z 18.7.2007 r., C-119/05. Nakaz windykacji bezprawnie przyznanej pomocy a zasada powagi rzeczy osqdzonej [Obligation of Recovery of un Unlawful State Aid and the Principle of Res Judicata], 'EPS' 2011, no 3, at pp. 44-50. 
of its decision. Res iudicata was no exception..$^{99}$ AG Villalón also stated that the obligation to recover aid was an obligation to achieve the result sought, not merely to take action. Member States are obliged to effectively execute such decisions and only absolute impossibility can relieve them from this duty, which was not the case in Frucona Košice. The AG also stated that in similar cases before the court, Member States must include in their legislation - apart from the provisions usually laid down in their respective legal systems for the revocation of the authority of res iudicata - a provision concerning the unlawfulness under Community law of judicial acts or decisions which have become final. However, the court did not base its judgment on the AG opinion but rather found that, under national law, there resources had been available to the national authorities which, if properly used, could have ensured that the Slovak Republic was able to recover the aid. ${ }^{100}$

Even though in Lucchini the court denied the Italian courts' judgments the force of res iudicata, that conclusion deserves approval. As the Italian courts rendered their judgments outside of their jurisdiction, the judgments could have no effect on EU law.

State aid is of course an area of centralized competence. It is therefore logical that the Court, although confronted with a question dealing with national procedural law, did not express itself in terms of effectiveness/equivalence, but in terms of supremacy. The rights/ enforcement dichotomy on which the relationship between national procedural law and EU law is based does not apply here.

The right of recovery is its enforcement. Thus, with supporting precedent being found in Simmenthal, it is clear that supremacy has a remedial dimension. The appropriate remedy in an area of supranational competence is therefore supremacy. No other would do and certainly not a Köbler-type damages action. A parallel can be found with competition law. In Eco Swiss the ECJ, after clarifying that competition law and Article $81 \mathrm{EC}$ are to be considered ordre publique rules, explained that the duty of national courts goes as far as to raise certain points related to application of competition law of their own motion. ${ }^{101}$

99 Position presented in para. 28 of the AG opinion.

100 Frucona Košice, Case no C-507/08, Judgment of 22.12.2010, EU:C:2010:802, at para. 61.

101 A. Biondi, C-119/05 Case Comment, 'CMLR' 2008, no 5. 
Frucona Košice is not so evident, as it differs from Lucchini in many respects. ${ }^{102}$ In Frucona Košice, the judgment of the national court preceded the Commission decision. Furthermore, in Lucchini, it was evident from the very beginning that Italian measures consisted state aid. That aid was notified to the Commission, which finally found it incompatible with the internal market and forbade the payment of it. In Frucona Košice, facts were different. The Slovak bankruptcy court, while approving the bankruptcy arrangement, had reasons to believe that the arrangement did not involve state aid. ${ }^{103}$ Not unlike in the G.I.E. fiscaux case, the judgment of the Slovak court predated the Commission decision to initiate a formal investigation procedure under Article 88(2) of the Treaty. ${ }^{104}$ Whereas in Lucchini there is no doubt that the Italian courts violated their jurisdiction by rendering judgments in a field of law reserved for the exclusive jurisdiction of the Commission, in Frucona Košice one cannot be so certain. As national courts have the power to examine the existence of state aid (rather than its compatibility with the internal market), it is evident that the Slovak court did not violate its jurisdiction.

Even if in Frucona Košice the Slovak court was wrong to find that the bankruptcy arrangement did not contain state aid, there is no ground on which to apply the reasoning from Lucchini for exclusion of the possibility to apply the res iudicata in this case. However, in Frucona Košice neither the AG in its opinion nor the court in its judgment convincingly decided if res iudicata can justify the non-enforcement of the Commission decision. Instead, the AG found that Member States must include in their legislation concerning the revocation of res iudicata, a provision on the unlawfulness of final judicial acts or decisions under Community law. The court failed to resolve the issue, as it limited itself to finding that, under Slovak law, certain steps could have been taken in order to recover the aid, and the Slovak Republic chose not to pursue the available course of action.

102 A. Birnstiel, Recovery of Unlawful State Aid: The Role of Member State Courts in State Aid Recovery Scenarios - Comments on Case C-507/08 and Case C-304/09 of 22 December 2010, 'EStAL' 2012, no 3, at p. 647.

${ }_{103}$ Regardless of the fact that the arrangement was made in accordance with the national bankruptcy law, at the time the domestic court rendered its judgment (i.e., in 2004), no legal proceedings were being conducted before the Commission with respect to Frucona Košice, which could raise any doubts as to the existence of aid. The Commission opened its investigation in 2005, long after the Slovak court had rendered its judgment, approving the arrangement.

${ }_{104} C(2006) 6629$, at para. 194. 
Compatibility of the State Aid Recovery Order with the General Principles...

The Frucona Košice case raises mixed feelings. From one point of view, the AG's opinion is both self-contradictory and at odds with EU law. It denies the final and binding judgments of national courts the force of res iudicata, while, at the same time, declaring it a general principle of EU law. Instead of basing its opinion on this principle, the AG stated that Member States should include in their national legal systems provisions for revoking national measures which could hinder the enforcement of Commission decisions. Had the court followed the line proposed in the AG's opinion, it could have limited the general principles of EU law to the principles of primacy and effectiveness, discarding anything else.

Maybe that was the reason why the court did not follow the line proposed by the $\mathrm{AG}$ and based its judgment on the finding that it was possible to recover the aid under the existing provisions of Slovak law. Making such a judgment was only a seeming departure from the opinion of the AG. Although the court did not openly follow the line proposed by the AG, it rejected the notion that the judgment of the national court could have a res iudicata force when it could pose an obstacle to the recovery of the aid under the Commission decision. The court clearly stated that the Slovak Republic had not used all measures available to it. The court did not notice, however, that Slovak national legal measures to which it referred came into force as late as in 2008 (i.e. four years after the bankruptcy arrangement had been made). The court also failed to realise that, even though it had not referred to res iudicata, it found that the Slovak Republic breached EU law because it had not applied its law retroactively.

The last issue concerns the fact that in Frucona Košice the issue of res iudicata was considered only during an application against the Slovak Republic for the non-enforcement of the Commission decision. Had it been considered during the application against the Commission decision, ${ }^{105}$ the outcome might have been different. In particular, the Commission could have issued its decision without ordering the recovery of aid, if the recovery was contrary to a general principle of EU law. Notwithstanding these doubts, the absence of a claim from an applicant before the GC does not limit the GC from deciding such matters of its own volition. In the France Télécom case, the Commission made it clear that it needed no motion from an applicant to find if the recovery of aid would be contrary to the general principles of EU law. ${ }^{106}$ This applies also to EU courts. Raising, at its own

$105 \quad C(2006) 2082$.

$106 \mathrm{C}(2004) 3060$, at paras 261-262. 
discretion, the issue of the general principles of EU law by an EU institution in the case of a powerful Member State, while clearly disregarding it in the case of a less powerful Member State, appears to justify the opinion that double standards are being employed by EU institutions. ${ }^{107}$

\subsection{The principle of national identity}

Unlike other general principles of EU law, which derive from the court's case law, ${ }^{108}$ the principle of national identity is based on a clear legal provision. It was introduced into EU law in 1992 by the Maastricht Treaty, Article F(1) of which reads as follows:

The Union shall respect the national identities of its Member States, whose systems of government are founded on the principles of democracy.

The clause was later revised in the Amsterdam Treaty (1997), where the second part of the sentence was removed, leaving only the following:

The Union shall respect the national identities of its Member States.

Finally, it was given its current reading in the Lisbon Treaty, which not only renumbered the articles of the TEU, ${ }^{109}$ but also gave Article 4(2) TEU a new shape:

The Union shall respect the equality of Member States before the Treaties as well as their national identities, inherent in their fundamental structures, political and constitutional, inclusive of regional and local self-government. It shall respect their essential State functions, including ensuring the territorial integrity of the State, maintaining law and order and safeguarding national security. In particular, national security remains the sole responsibility of each Member State.

107 N. Półtorak, Ochrona uprawnień wynikających z prawa Unii Europejskiej w postępowaniach krajowych [Protection of EU Law Rights in National Procedures], LEX a Wolters Kluwer Business, Warszawa 2010, at p. 86.

108 A. Cieśliński, Wspólnotowe..., op. cit., at p. 11; C. Mik, Europejskie..., op. cit., at p. 486.

${ }^{109}$ Article F TEU became Article 4. 
Compatibility of the State Aid Recovery Order with the General Principles...

The principle of national identity stems from the fundamental structures of Member States and from their constitutions, including regional and local self-governments. A range of values which can seek protection under this principle is unlimited, and it is for Member States to decide which values are so important to them that they must be protected under the principle of national identity. The EU and its institutions are not competent to decide what constitutes a Member State's national identity. ${ }^{110}$

A Member State's decisions on matters concerning EU law do not generally ${ }^{111}$ bind EU institutions; although, EU courts have the jurisdiction to adjudicate any disputes deriving from it. EU courts can state that, while a certain value put forward by a Member State does, in fact, deserve protection under the principle of national identity, the State cannot rely on the principle in a particular case, e.g. due to the disproportionality of national measures. ${ }^{112}$

Although the principle of national identity has been present in EU law since the Maastricht Treaty and was occasionally invoked on both sides of disputes before EU courts and Advocates General, EU courts have rarely recognised the European Union's obligation to respect this principle. Cases where the court has found this principle worthy of a judicial protection are even scarcer. Before the Treaty of Lisbon entered into force, only once had the court expressly referred to this principle. ${ }^{113}$

Even though, on some occasions, the court considered the principle of national identity to be a means for adjudicating cases, even basing its judgments thereon, it nevertheless refrained from making any explicit reference to it, ${ }^{114}$ referring to national constitutions instead.

The court's reluctance to employ the principle of national identity in its considerations seems to have abated after the Treaty of Lisbon came into force. Since that date, the court has referred to the principle of national identity more frequently. ${ }^{115}$ However, many of these new cases were

110 L.F.M. Besselink, National and Constitutional Identity before and after Lisbon, 'Utrecht Law Review' 2010, vol. 6, no 3, at pp. 36-49.

111 Unless EU law provides otherwise.

112 Michaniki, infra, Opinion AG Maduro, EU:C:2008:544.

113 Commission/Luxemburg, Case no C-473/93, Judgment of 2.7.1996, EU:C:1996:263, at para. 36 .

114 Michaniki, Case no C-213/07, Judgment of 16.12.2008, EU:C:2008:731; Omega, Case no C-36/02, Judgment of 14.10.2004, EU:C:2004:614.

115 Sayn-Wittgenstein, Case no C-208/09, Judgment of 22.12.2010, EU:C:2010:806, at paras 83 and 92; Runevič-Vardyn, Case no C-391/09, Judgment of 12.5.2011, 
unsuccessful for the parties invoking the principle of national identity, mostly due to the disproportionality of national measures. On the other hand, the cases which were successful for parties relying on the principle of national identity turned out to be of a non-commercial character or cases in which the commercial element was less pronounced.

It is particularly notable that the number of cases in which the court has referred to the principle of national identity has risen only after the Treaty of Lisbon. The reason for this could be that before the Treaty of Lisbon, the court did not have jurisdiction to adjudicate claims based on the principle of national identity. ${ }^{116}$ This argument is, however, unconvincing. In Commission/Luxemburg, the court based its judgment on the principle of national identity, ${ }^{117}$ despite the fact that the case predated the Treaty of Lisbon. Furthermore, judgments based, in that period, on fundamental rights bear a strong resemblance to judgments on national identity. The fundamental rights clause, similarly to the national identity clause, was originally excluded from the then Article L, which preceded Article 46 TEU. Nonetheless, it had not stopped the court from adjudicating on fundamental rights. ${ }^{118}$

According to the well-established case law of EU courts, EU law has absolute primacy over national law, regardless of its nature, ${ }^{119}$ which also means the absolute primacy over Member States' constitutions. ${ }^{120}$ This conclusion differs from the position taken by national constitutional or

EU:C:2011:291, at para. 86; Commission/Luxemburg, Case no C-51/08, Judgment of 24.5.2011, EU:C:2011:336, para 124; O’Brien, Case no C-393/10, Judgment of 1.3.2011, EU:C:2012:110, at para. 49; Las, Case no C-202/11, Judgment of 16.4.2013, EU:C:2013:239, at para. 26; Torresi, Cases no C-58/13 and C-59/13, Judgment of 17.7.2014, EU:C:2014:2088, at paras 56-59, Bogendorff, Case no C-438/14, Judgment of 2.6.2014, EU:C:2016:401, at para. 64; Balázs-Árpád Izsák/Commission, Case no T-529/13, Judgment of 10.5.2016, EU:T:2016:282, at para. 70.

116 L.F.M. Besselink, Respecting Constitutional Identity in the UE, Case Note to Case C-208/09, Sayn-Wittgenstein v. Landeshauptmann von Wien, Judgment of the Court (Second Chamber) of 22 December 2010, NYR, 'CMLR' 2012, no 4, at pp. 671-694.

117 Commission/Luxemburg, Case no C-473/93, supra, at para. 36.

118 E. Cloots, National Identity in EU Law, Oxford University Press, Oxford 2015, at p. 66 .

119 Judgment Flaminio Costa/E.N.E.L., supra; Simmenthal, Case no C-106/77, Judgment of 9.3.1978, EU:C:1978:49, at para. 17.

120 Internationale Handelsgesellschaft mbH/Einfuhr und Vorratsstelle für Getreide und Futtermittel, Case no C-11/70, Judgment of 17.12.1970, EU:C:1970:114. 
supreme courts, including German ${ }^{121}$ and Polish ${ }^{122}$ constitutional courts, which emphasise that the primacy of EU law does not extend to national constitutions.

It depends on the character of the system of EU law whether such conflicting positions can be reconciled. If its character is hierarchical, then positions taken by national constitutional or supreme courts have no legal basis. If, on the other hand, the system of EU law, composed of the law made by EU institutions and the law of Member States, is not hierarchical but rather multi-centric ${ }^{123}$ or composite, ${ }^{124}$ then it is possible that such differences can be resolved. It would not then be necessary to grant EU law absolute primacy over national laws of Member States for the sake of the effectiveness of the former.

The characteristic feature of a composite structure (Verbund) is the intertwining of cooperation and hierarchy as ordering paradigms for the conduct of actors in the European legal space. The concept of composite constitutionalism transcends traditional and somewhat simplistic ideas about the relationship between different constitutional orders, especially those that operate with simple supra- and subordination, where one legal order necessarily trumps another. Instead, the Verbund concept highlights both the autonomy of the actors at EU and national levels, and their mutual dependence in their quest to achieve common aims, thus requiring loyal cooperation and the submission to a uniform legal regime. ${ }^{125}$

The court starts to notice the need for protecting the national identity of MemberStates. Even though it has found that it would bejustifiable for national constitutions to take precedence over EU law only in extremely rare cases, ${ }^{126}$

\footnotetext{
121 Judgment BVerfGE, supra, at paras 37, 73, 89.

122 Judgment of 11.5.2005, K 18/04; Judgment of 24.11.2010, K 32/09; Judgment of 16.11.2011, K 45/09.

123 E. Łętowska, Dialog i metody. Interpretacja $w$ multicentrycznym systemie prawa
} (part I) [The Dialogue and the methods. Interpretation in a Multicentric Legal System], 'EPS' 2008, no 11, at p. 4; E. Łętowska, Dialog i metody. Interpretacja w multicentrycznym systemie prawa (part II), 'EPS' 2008, no 12, at p. 4.

124 D. Thym, In the Name of Sovereign Statehood: A Critical Introduction to the Lisbon Judgment of the German Constitutional Court, 'CMLR' 2009, vol. 46, at pp. 1795-1822, A. Von Bogdandy, S. Schill, Overcoming Absolute Primacy: Respect for National Identity under the Lisbon Treaty, 'CMLR' 2011, vol. 48, at pp. 1417-1454.

125 A. Von Bogdandy and S. Schill, Overcoming..., op. cit.

126 See e.g. opinion AG Maduro in case Michaniki, supra, at para. 31; Judgment SaynWittgenstein, supra, at paras 83 and 92. 
and only after strict requirements have been met, the very acceptance of that notion suggests that the primacy of EU law has lost its absolute character.

Some believe that yet another solution should be adopted, ${ }^{127}$ with the appropriate way to settle disputes being the application of the sincere cooperation principle. In the course of such cooperation, the Member State would have to determine the content of its national identity, while the court would only be entitled to decide on the relevance of national identity under EU law. ${ }^{128}$ The court cannot, however, take it upon itself to perform the examination which is to be carried out by the Member State.

The finding that it is for the Member State to decide which values are covered by its national identity does not provide an answer - if it has any significance from the court's perspective - to the question as to who in that State is to decide whether a given value ought to be covered by national identity. As the current case law of the court suggests, this issue is of significance for the scope and intensity of examination performed by the court, which can vary depending on whether the opinion submitted in the case is that of a national constitutional court or a supreme court.

The ECJ may be a more active censor than national constitutional courts, but Sayn-Wittgenstein (and Omega) suggests that it is more indulgent and tolerant if the national constitutional court has pronounced on the matter. In the cases mentioned above where an appeal to national constitutional identity was rejected, no national constitutional court had clarified the national status and meaning of the constitutional norm or principle. ${ }^{129}$

Moreover, the court's case law suggests that it is not only the person with the power to decide on the national identity that matters but also the issue of whether the case under examination has an economic or non-economic character. The cases of a non-economic character are more likely to receive protection under the principle of national identity.

State aid cases have a clearly economic character and, by definition, may affect the internal market. As the court states, a recovery order is a logical consequence of finding that the aid is unlawful [rather than incompatible with the internal market - M.R.], and it is granted for the purpose of re-establishing the situation existing before the aid was granted. In the current

A. Von Bogdandy and S. Schill, Overcoming..., op. cit.

A. Von Bogdandy and S. Schill, Overcoming..., op. cit.

L.F.M. Besselink, Respecting..., op. cit. 
Compatibility of the State Aid Recovery Order with the General Principles...

state of the court's case law, it would be highly unlikely for EU courts to adjudge that the EC have breached the principle of national identity by ordering a Member State to recover state aid. This view is supported by the fact that EU courts have yet to make a single judgment in which they would state that, by ordering a Member State to recover aid, the EC breached the principle of national identity. What is more, the court has so far acknowledged only values which do not have an economic character or whose economic character is lower than the value said to be covered by the national identity.

On the other hand, the fact that EU courts have not yet referred to the principle of national identity in state aid cases cannot serve as conclusive evidence that such a verdict is not to be made. It may be unlikely, but it is by no means impossible. National identity clause is not limited (formally) to particular areas of law, and it is for Member States to decide which values fall under their national identity. The court has, thus far, made but a few judgments referring to the principle of national identity; however, the relevant case law is only now being built and one may expect more judgments on the issue. Although in cases of an economic character (which would also apply to state aid) the court performs a stricter examination of the proportionality than in cases of a non-economic character, the scope of such an examination is yet to be established.

Therefore, the author of this paper believes that, even though it would be a virtually isolated case, it is not impossible to successfully invoke the principle of national identity in state aid cases, in order to evade the recovery of the aid. ${ }^{130}$

\section{Fundamental human rights as the general principles of EU law}

\subsection{Introduction}

\section{Under Article 6 TEU:}

The Union recognises the rights, freedoms and principles set out in the Charter of Fundamental Rights of the European Union [...], which shall have the same legal value as the Treaties. [...] The Union shall

130 M. Rzotkiewicz, National Identity as a General Principle of EU Law and its Impact on the Obligation to Recover State Aid, 'YARS' 2016, vol. 9(13), at pp. 43-60. 
accede to the European Convention for the Protection of Human Rights and Fundamental Freedoms [ECPHR]. [...] Fundamental rights, as guaranteed by the European Convention for the Protection of Human Rights and Fundamental Freedoms and as they result from the constitutional traditions common to the Member States, shall constitute general principles of the Union's law.

Article 6 TEU makes a distinction between rights, freedoms, and principles set out in the CFR, which shall have the same legal value as the Treaties; however, it does not clarify the difference. This difference may manifest itself in the fact that rights and freedoms contained in the CFR are individual claims protected by courts, what is not the case with regard to principles. ${ }^{131}$ This would also mean that the rights and freedoms contained in the CFR are directly applicable, if only norms derived from CFR are directly effective. ${ }^{132}$

Apart from the rights, freedoms, and principles stipulated in the CFR, Article 6 TEU also refers to fundamental rights resulting from constitutional traditions common to Member States and guaranteed by the ECPHR. This provision underlines the position of fundamental human rights in the EU legal system, by stating that they constitute a part of EU law, as its general principles. ${ }^{133}$

Raising the position of fundamental human rights to that of general principles of law is a significant achievement. This is particularly true since, for a long time, the court denied such protection to individuals. The breakthrough came in the Stauder case, where the court pronounced that fundamental human rights are enshrined in the general principles of Community law and protected by the court. ${ }^{134}$ Next came the Internationale Handelsgesellschaft, Nold, and Rutili cases, in which the court stated that

131

C. Mik, Karta Praw Podstawowych: Wyznaczniki standardów ochronnych [Charter of Fundamental Rights. Determinants of Standards of Protection] [in:] J. Barcz (ed.), 'Ochrona praw podstawowych w Unii Europejskiej' [Protection of Fundamental Rights in the European Union], C.H. Beck, Warszawa 2008, at pp. 66-67.

132 A. Wyrozumska, Inkorporacja Karty Praw Podstawowych do prawa UE: Status Karty $w$ prawie UE, zakres obowiq̨zywania i stosowania, główne problemy interpretacyjne z uwzględnieniem stanowiska polskiego [Incorporation of Charter of Fundamental Rights to the EU Law] [in:] J. Barcz (ed.), 'Ochrona praw podstawowych...', op. cit, at p. 84.

${ }_{133}$ C. Mik, Komentarz do art. 6 TUE [Commentary on Article 6 TEU] [in:] W. Czapliński, C. Mik, 'Traktat o Unii Europejskiej. Komentarz' [A Commentary on the Treaty on European Union], ABC, 2005.

${ }^{134}$ Judgment Stauder, supra, at para. 7. 
respect for fundamental rights forms an integral part of the general principles of law protected by the Court of Justice, ${ }^{135}$ and it cannot uphold measures which are incompatible with fundamental rights recognised and protected by the constitutions of Member States. ${ }^{136}$ The court also pointed at the Convention for the Protection of Human Rights as containing principles which must be protected by EU law. ${ }^{137}$

This tendency to strengthen the role of human rights is reflected in the Joint Declaration by the European Parliament, the Council, and the Commission concerning the Protection of Fundamental Rights and the European Convention for the Protection of Human Rights and Fundamental Freedoms. ${ }^{138}$ However, as the declaration in question had no legal force, its significance was chiefly moral and political. ${ }^{139}$

The increasing role of fundamental rights was also confirmed in the preamble to the Single European Act, in Article F.2 of the Maastricht Treaty, and in the Nice Treaty, amending Article 46d TEU. The last amendment was made by the Treaty of Lisbon, altering Article 6 TEU.

Fundamental human rights are now considered to be primary law. ${ }^{140}$ This improves an imperfect situation where the position of fundamental human rights, being mainly the result of the courts' case law, affected legal certainty. Similarly, the court's attachment to values protected by fundamental human rights, although frequently declared, was often forgotten when it came to its practical application.

Further improvement of the status of fundamental human rights in the EU legal system - as well as of the protection of individuals' rights, stemming from fundamental human rights - should result from the upcoming accession of the EU to the ECPHR. The idea of the accession dates back to $1979,{ }^{141}$ when it was initially disregarded, only to resurface in 1994 with the Council seeking the court's advice on the matter. However, the

Judgment Internationale Handelsgesellschaft, EU:C:1970:114, at para. 4.

136 Judgment Nold, supra, at para. 13.

137 Judgment Rutili, supra, at para. 32

138 OJ 27.4.1977, C 103 p. 1.

139 A. Płachta, Zasada ochrony praw podstawowych [The Principle of Protection of Fundamental Rights] [in:] A. Wróbel (ed.), 'Stosowanie...' op. cit., at p. 281.

140 K. Lenaerts, J.A. Gutiérrez-Fons, The Constitutional Allocation of Powers and General Principles of EU Law, 'CMLR' 2010, vol. 47, at pp. 1629-1669.

141 The Commission's Memorandum on the Accession of the Communities to the European Convention for the Protection of Human Rights and Fundamental Freedoms. 
opinion of the court was negative, due to a lack of a firm legal basis for such an accession. ${ }^{142}$

That obstacle lost its ground after the amendment of Article 6 TEU under the Treaty of Lisbon, and, since then, the accession process gained momentum. In 2013, the Commission asked the court to issue an opinion on the compatibility of the draft agreement with EU law, pursuant to Article 218(11) TfEU. ${ }^{143}$ In the meantime, another obstacle to the EU accession to the ECPHR disappeared when Russia ratified Protocol No. 14 to the ECPHR. ${ }^{144}$

Should the EU accede to the ECPHR, EU institutions, similarly as Member States, would be obliged to follow all fundamental rights. ${ }^{145}$ This would also limit the current jurisdictional competition between the court and the ECtHR with regard to fundamental human rights, raising the level of individuals' protection and legal security through making court judgments more predictable. ${ }^{146}$ It should also allow the ECtHR to control the CFR, which would positively influence the cohesion of European fundamental human rights protection. ${ }^{147}$ It is hard to overestimate these advantages from the perspective of the protection of individuals, yet, on 18 December 2014, the court issued another negative opinion, stopping the accession process.

The significance of fundamental human rights manifests itself also in state aid law. During proceedings before the EU courts, the parties to the proceedings frequently claim a breach of such fundamental human

142 Case no 2/94, Opinion of 28.3.1996, EU:C:1996:140.

143 OJ 7.09.2013 C 260, p. 19.

144 A. Florczak, Ewolucja ochrony praw człowieka w systemie prawa wspólnotowego [Evolution of Protection of Human Rights in the Community Law Sytem] [in:] 'Ochrona praw podstawowych w Unii Europejskiej', Wydawnictwa Akademickie i Profesjonalne, Warszawa 2009, at p. 37.

145 D. Kornobis-Romanowska, Umocnienie statusu jednostek $w$ UE po przystapieniu $U E$ do $E K P C z$, Konsekwencje dla ustawodawcy i sadów krajowych - następstwa praktyczne [Reinforcement of the Position of Individuals in the EU after EU's Accession to the ECHR] [in:] J. Barcz (ed.) 'Ochrona praw podstawowych...', at p. 313.

${ }_{146}$ C. Mik, Znaczenie postanowień EKPCz dla ochrony praw podstawowych jako ogólnych zasad prawa w UE [The Role of ECHR Dispositions in Fundamental Rights Protection as General Principle of Law in the EU] [in:] J. Barcz (ed.) 'Ochrona praw podstawowych...', at p. 223.

147 Z. Kędzia, Relacje między Europejskq Konwencją Praw Człowieka a Kartq Praw Podstawowych po przystapieniu Unii Europejskiej do Konwencji [Relations between the ECHR and the CFR after the accession of the EU to the ECHR] [in:] J. Barcz (ed.) 'Ochrona praw podstawowych..., at p. 246. 
rights ${ }^{148}$ as the right of defence, ${ }^{149}$ the right to ownership, ${ }^{150}$ the ne bis in idem principle, ${ }^{151}$ or the right to good administration. ${ }^{152}$ However, the effectiveness of such claims - and supporting arguments - varies. Due to the fact that a breach of good administration, such as a failure to comply with the duty to state reasons, may lead to the annulment of a decision, ${ }^{153}$ beneficiaries' claims concerning the Commission violating the right of defence are consistently denied. ${ }^{154}$ Hence, not all fundamental human rights claimed before the court matter in state aid cases. The ne bis in idem principle is virtually of no significance, as EU courts follow their case law indicating that the recovery of aid is not a penalty but rather a logical consequence of finding aid to be unlawful (rather than incompatible with the internal market). Arguments based on the right to conduct business activity are similarly ineffective.

If a defence based on fundamental human rights is to be effective, such rights must not only be recognised by EU law but also constitute its general principles. Furthermore, concrete rights derived from fundamental human rights must not be contrary to the goals pursued by the EU. Due to this fact, in the following part the reference was made only to those rights that were recognised in the court's case law, such as the right of defence (to the extent that it is claimed by Member States), and the right to good administration. Though claiming those rights is also rarely effective, their significance among fundamental human rights recognised as the general principles of EU law makes it necessary to refer to them.

148 In Buczek Automotive, infra, the party claimed that the Commission violated Article 41 CFR.

149 Judgment Scott, supra, at para. 54; TV2/Denmark, Case no T-309/04, Judgment of 22.10.2008, EU:T:2008:457, at para. 84; EDF, Case no T-156/04, Judgment of 15.12.2009, EU:T:2009:505, at para. 66.

150 Judgment Westdeutsche Landesbank Girozentrale, supra, at para. 185; CDA Datenträger, Case no T-324/00, Judgment of 19.10.2005, EU:T:2005:364, at para. 66; Judgment ThyssenKrupp, supra, at para. 33.

151 Olympiaki Aeroporia Ypiresies, Case no T-68/03, Judgment of 12.9.2007, EU:T:2007:253, at para. 57; Olympiakes Aerogrammes AE, Joint Cases no T-415/05, T-416/05, and T-423/05, Judgment of 13.9.2010, EU:T:2010:386, at paras 414-418.

152 Judgment González y Díez, supra, at par. 82, and Cantiere Navale, Case no T-584/08, Judgment of 3.2.2011, EU:T:2011:26, at paras 86-90.

153 Judgment Buczek Automotive, supra, at para. 98.

154 The right of defence may be claimed only by such parties to Commission proceedings whose rights had been breached in the course of said proceedings. As beneficiaries are not parties to such proceedings (only Member States are), they are not entitled to seek protection under the right of defence. 


\subsection{Right of defence}

The right of defence plays a potent role in criminal law, ${ }^{155}$ as one of the main principles of the legal system safeguarding law and order. However, the significance of this principle goes beyond criminal law and is particularly important in administrative law, e.g. in competition law. ${ }^{156}$ It was granted international recognition, as evidenced by Article 6 ECPHR (the right to a fair trial), in Article 41 CFR (a part of the right to good administration), and in Article $48 \mathrm{CFR}$ (the presumption of innocence and the right of defence).

Irrespective of the field, the right of defence states that a person who may be adversely affected by a legal verdict (judicial or administrative) is entitled to take any available legal steps to protect rights. ${ }^{157}$ In EU law, this has been illustrated by the Lisretal case:

[R]espect for the rights of the defence in all proceedings which are initiated against a person and are liable to culminate in a measure adversely affecting that person is a fundamental principle of Community law which must be guaranteed, even in the absence of any specific rules concerning the proceedings in question. ${ }^{158}$

The right of defence can be relied on by persons against whom proceedings ("which are initiated against a person") are conducted. Under the current case law, this right cannot be claimed by persons adversely affected by legal measures where the proceedings are not formally conducted against them, i.e. where such persons are not parties to the proceedings. This is particularly evident in state aid cases.

The right of defence encompasses a wide range of rights, both active and passive. Within the right of defence, one may distinguish the right to actively participate in legal proceedings, including the right to seek

155 T. Marguery, European Union Fundamental Rights and Member States Action in EU Criminal Law, 'Maastricht Journal' 2013, vol. 20, at p. 283.

156 R. Zenc, Prawo do obrony we wspólnotowym prawie konkurencji [Rights of Defence in Community Competition Law] [in:] C. Mik, K. Gałka (eds) 'Prawa podstawowe w prawie i praktyce Unii Europejskiej' [Fundamental Rights in Law and Practice of the EU], TNOIK Torun, 2009, at p. 429.

157 E. Barbier de La Serre, Procedural Justice in the European Community Case Law Concerning the Rights of the Defence: Essentialist and Instrumental Trends, 'European Public Law' 2006, vol. 12, at pp. 225-250.

158 Lisretal, Case no T-450/93, Judgment of 6.12.1994, EU:T:1994:290, at para. 42. 
Compatibility of the State Aid Recovery Order with the General Principles...

information related to the proceedings and access the relevant documents. ${ }^{159}$ It also entitles one to file motions that are to be considered, ${ }^{160}$ present information related to the case, and comment on all circumstances which could influence the rights and obligations of the person. ${ }^{161}$

Respect for the rights of the defence in all proceedings in which sanctions may be imposed is a fundamental principle of Community law which must be respected in all circumstances, even if the proceedings in question are administrative proceedings. The proper observance of that general principle requires that the undertaking concerned be afforded the opportunity during the administrative procedure to make known its views on the truth and relevance of the facts, charges and circumstances relied on by the Commission. ${ }^{162}$

A refusal to provide information falls under the protection of the right of defence where disseminating such information would adversely affect the legal rights of a person relying on the right of defence. ${ }^{163}$

When applying the right of defence to state aid cases, it is evident that adverse consequences of these cases mostly affect the aid beneficiaries, rather than Member States. Beneficiaries must be aware that a Member State may reclaim the previously granted aid. Furthermore, the Commission may order a Member State not to grant additional aid to a beneficiary who failed to return the aid previously granted. It is true that certain negative consequences affect also Member States, obliged as they are to recover any aid that has been challenged by the Commission; nevertheless, the beneficiaries, rather than Member States, face the gravest consequences of the Commission decisions. They may even be forced to close their businesses, should the Commission deem it a feasible way of enforcing its decision.

159 BPB Industries, Case no T-65/89, Judgment of 1.4.1993, EU:T:1993:31, at para. 30; Cimenteries CBR, Joint Cases T-10/92 to T-12/92 and T-15/92, Judgment of 18.12.1992, EU:T:1992:123, at para. 38.

160 J. Flattery, Balancing Efficiency and Justice in EU Competition Law: Elements of Procedural Fairness and Their Impact on the Right to a Fair Hearing, 'CompLRev' 2010, vol. 7, no 1 , at p. 55.

${ }_{161}$ M. Varju, European Union Human Rights Law: The Dynamics of Interpretation and Context, Edward Elgar Publishing Limited, 2014, at p. 164.

162 Solvay, Case no T-30/91, Judgment of 29.6.1995, EU:T:1995:115, at para. 59.

${ }^{163}$ K. Kowalik-Bańczyk, Procedural Autonomy of Member States and the EU Rights of Defence in Antitrust Proceedings, 'YARS' 2012, vol. 5(6), at p. 23. 
In the absence of a full and immediate repayment of the unlawful and incompatible aid, the authorities responsible for the execution of the recovery decision should take all measures available to oppose the adoption of a continuation plan and should insist on the ending of the activity of the beneficiary within the time limit set in the recovery decision. ${ }^{164}$

Yet, in state aid cases, persons adversely affected by legal proceedings are deprived of the right of defence. ${ }^{165}$ In state aid cases, the right of defence may neither be claimed by aid beneficiaries nor by their competitors. Only Member States enjoy such a right.

The case of France Télécom provides a practical example of the application of the right of defence by the Commission. The Commission found that France had granted unlawful and incompatible aid. Regardless of that finding, the Commission stated that ordering France to recover that aid would violate France's right of defence. Consequently, under Article 14.1 of Regulation 659/1999, the Commission refrained from issuing such an order. $^{166}$

The right of defence may, thus, be claimed only by Member States, and not by the beneficiaries from whom the aid is to be recovered. This is despite the fact that the gravest consequences of Commission decisions are borne by the beneficiaries rather than by Member States.

164 Notice from the Commission - Towards an effective implementation of Commission decisions ordering Member States to recover unlawful and incompatible State aid, at para. 67.

165 It is all the more doubtful since the Commission frequently advocates for direct application of the Commission decisions ordering Member States to recover aid. As follows from the Study on the Enforcement of State Aid Law at National Level, Part I, at p. 52, some countries meet that expectation.

166 In many respects, this decision is unclear. The Commission found that France had granted unlawful and incompatible aid. What is more, the form in which the aid was granted was determined. Nevertheless, the Commission stated that, since it had been unable to determine the exact amount of aid, the respect for the Member State's rights of defence might constitute an obstacle to the recovery of the aid. This conclusion was supported by legitimate expectations. It is not clear why the Commission decided that difficulties it had encountered in calculating the aid prohibited it from issuing a recovery order. Especially, since in other cases supported by the court's case law the Commission did not hesitate to order Member States to make appropriate calculations of aid to be recovered. Additionally, the Commission justified its decision by legitimate expectations, regardless of the fact that legitimate expectations may not be claimed by Member States, and it was a Member State (France), rather than a beneficiary (FT), that was a party to the proceedings. 
Compatibility of the State Aid Recovery Order with the General Principles...

In fact, State aid enforcement has been rather draconic: the Polish shipyard example, where the inability of repayment of aid that was ex-post deemed unlawful has led to bankruptcy and unemployment could hardly have been more drastic. ${ }^{167}$

Examining the right of defence from this perspective, the frequent references by EU courts to the general principles of EU law are not supported by facts. Attempts are often made to justify this disparity by pointing out that the right of defence may only be claimed by parties to proceedings, thus excluding the beneficiaries since such proceedings are conducted against Member States. ${ }^{168}$ This reasoning may be taken even further, leading to the conclusion that beneficiaries, despite not being parties to proceedings, are considered interested parties and entitled to participate in the proceedings, as justified by circumstances. ${ }^{169}$

Such arguments are highly unsatisfactory, as those who bear the gravest consequences of Commission decisions are deprived of the opportunity to effectively defend their legal interests. Nevertheless, Member States are the ones afforded the status of a party to proceedings before the Commission. Beneficiaries are not given the same right, even though a Commission decision may force them out of business; they are regarded as nothing more than a source of information ${ }^{170}$ which may then be used by the Commission, at its own discretion, in the course of proceedings that are formally conducted against a Member State but substantially against the beneficiary.

Such arguments also disregard the fact that it is not the purpose of the right of defence to allow persons to provide evidence against themselves but rather to offer them an opportunity to actively fight the adverse results of legal proceedings. ${ }^{171}$ It can be even said that, in EU state aid law, the legal status afforded to beneficiaries diminishes the procedural guarantees of the interested parties. ${ }^{172}$

167 J. Holscher, N. Nulsch, J. Stephan, Ten Years after Accession: State Aid in Eastern Europe, 'EStAL' 2014, no 2, at pp. 305-316.

168 Falck, Case no C-74/00, Judgment of 24.9.2002, EU:C:2002:524, at para. 81.

169 Judgment TV 2/Denmark, supra, at para. 137.

170 Judgment Scott, supra, at para. 53.

171 S. White, Rights of the Defence in Administrative Investigations: Access to File in EC Investigations, 'Review of European Administrative Law' 2009, vol. 2, no 1, at pp. 55-67.

172 H.P. Nehl, The Imperfect Procedural Status of Beneficiaries of Aid in EC State Aid Proceedings - Note on Case C-276/03 P, Scott S.A. v. Commission, 'EStAL' 2006, no 1, at p. 57. 
Due to the above shortcomings, the legal status of a beneficiary in state aid law requires urgent intervention. Such intervention should be made either by way of legislative or case law changes. EU courts easily pronounce their attachment to the general principles of law, derived from constitutional traditions common to all Member States. At the same time, these courts with equal ease deny beneficiaries the effective right of defence, even though the latter bear the gravest consequences of Commission decisions. ${ }^{173}$

\subsection{The right to good administration}

The right to good administration derives from (i) constitutional traditions common to all Member States, (ii) international agreements on human rights, to which Member States are parties, and (iii) EU law. ${ }^{174}$ It was defined in Article 41 of the CFR:

1. Every person has the right to have his or her affairs handled impartially, fairly and within a reasonable time by the institutions, bodies, offices and agencies of the Union.

2. This right includes:

(a) the right of every person to be heard, before any individual measure which would affect him or her adversely is taken;

(b) the right of every person to have access to his or her file, while respecting the legitimate interests of confidentiality and of professional and business secrecy;

(c) the obligation of the administration to give reasons for its decisions.

3. Every person has the right to have the Union make good any damage caused by its institutions or by its servants in the performance of their duties, in accordance with the general principles common to the laws of the Member States.

4. Every person may write to the institutions of the Union in one of the languages of the Treaties and must have an answer in the same language.

173 H.P. Nehl, 2013 Reform of EU State Aid Procedures: How to Exacerbate the Imbalance between Efficiency and Individual Protection, 'EStAL' 2014, no 2, at pp. 235-249.

174 A. Dauter-Kozłowska, Prawo do dobrej administracji w Karcie Praw Podstawowych Unii Europejskiej i w Świetle Europejskiego Kodeksu Dobrej Administracji [Right to Good Administration in CFR and in the light of European Code of Good Administrative Behaviour] [in:] C. Mik, K. Gałka (eds), op. cit., at p. 338. 
Compatibility of the State Aid Recovery Order with the General Principles...

The right to good administration has been defined in a general way. Any person concerned with administrative proceedings, regardless of their citizenship, is entitled to claim that right. Neither has it been limited to parties to the proceedings, or, in the case of state aid law, to EU Member States. Thus, any person who may be adversely affected by an administrative measure may claim that right, especially since it has been defined as a human right.

Under Article 41 CFR, the right to good administration comprises the right of defence and the obligation to give reasons. Since the Treaty of Lisbon came into force, endowing the CFR with legal force equal to that of the Treaties, EU courts may no longer deny beneficiaries who are not parties to proceedings before the Commission their right of defence. The right of defence, contained in the right to good administration, is a human right and anyone who may be adversely affected by administrative measures may seek protection under that right, regardless of being formally considered a party to the proceedings.

\section{Conclusion}

The general principles of EU law play a significant role in state aid law; consequently, the decisions ordering the recovery of incompatible aid should not be contrary to these principles.

At least, this is the theory. The practical impact of the aforementioned principles is much lower than desired, as neither the Commission nor EU courts are consistent in their application of Article 16.1 of the Procedural Regulation. They emphasise their attachment to the principles, going as far as to say that such principles must be taken into consideration without being invoked by those affected. Yet, on many occasions, neither EU courts nor the Commission see the need to take these principles into account and, more often than not, the conclusions of these institutions lack any reference in this regard, irrespective of the claims raised by the parties to the proceedings.

The present situation can be expected to change following EU accession to the ECPHR, which may result in improving the level of legal certainty; however, at least for now, this process has been halted by the court. ${ }^{175}$

175 Opinion of the court 2/13 pursuant to Article 218(11) TfEU - draft international agreement - Accession of the European Union to the European Convention for the Protection of Human Rights and Fundamental Freedoms - Compatibility of the draft agreement with the EU and TfEU Treaties, ECLI:EU:C:2014:2454. 


\section{Bibliography}

1. Baran M., Glosa do wyroku TS z 18.7.2007 r., C-119/05. Nakaz windykacji bezprawnie przyznanej pomocy a zasada powagi rzeczy osadzonej, 'EPS' 2011, no 3.

2. Barbier de La Serre E., Procedural Justice in the European Community Case Law Concerning the Rights of the Defence: Essentialist and Instrumental Trends, 'European Public Law' 2006, vol. 12.

3. Barents R., Directory of EC Case Law on State Aids, Kluwer Law International, 2008.

4. Besselink L.F.M., National and Constitutional Identity before and after Lisbon, 'Utrecht Law Review' 2010, vol. 6, no 3.

5. Besselink L.F.M., Respecting Constitutional Identity in the UE, Case Note to Case C-208/09, Sayn-Wittgenstein v. Landeshauptmann von Wien, Judgment of the Court (Second Chamber) of 22 December 2010, NYR, 'CMLR' 2012, no 4.

6. Biernat S., Źródła prawa Unii Europejskiej [in:] J. Barcz (ed.) 'Prawo Unii Europejskiej, Zagadnienia systemowe', Warszawa 2003.

7. Biondi A., C-119/05 Case Comment, 'CMLR' 2008, no 5.

8. Birnstiel A., Recovery of Unlawful State Aid: The Role of Member State Courts in State Aid Recovery Scenarios - Comments on Case C-507/08 and Case C-304/09 of 22 December 2010, 'EStAL' 2012, no 3.

9. Brandtner B., Recovery and Insolvency - a Case for Greater Flexibility? 'GCLC Lunch Talk', 24.6.2013.

10. Cieśliński A., Wspólnotowe prawo gospodarcze, C.H.Beck, Warszawa 2003.

11. Cloots E., National Identity in EU Law, Oxford University Press, Oxford 2015.

12. Craig P., De Búrca G., EU Law: Text, Cases and Materials, Sixth Edition, Oxford University Press, 2015.

13. Craig P., The ECJ and Ultra Vires Action: A Conceptual Analysis, 'CMLR' 2011, no 2.

14. Dauter-Kozłowska A., Prawo do dobrej administracji w Karcie Praw Podstawowych Unii Europejskiej i w świetle Europejskiego Kodeksu Dobrej Administracji [in:] C. Mik, K. Gałka (eds), 'Prawa podstawowe w prawie i praktyce Unii Europejskiej’, TNOIK Toruń, 2009.

15. Flattery J., Balancing Efficiency and Justice in EU Competition Law: Elements of Procedural Fairness and their Impact on the Right to a Fair Hearing, 'CompLRev' 2010, vol. 7.

16. Florczak A., Ewolucja ochrony praw człowieka w systemie prawa wspólnotowego [in:] 'Ochrona praw podstawowych w Unii Europejskiej', Wydawnictwa Akademickie i Profesjonalne, Warszawa 2009.

17. Fontanelli F., The European Union's Charter of Fundamental Rights Two Years Later, Centro Studi Sul Federalismo 2011, vol. 3, no 3.

18. Giraud A., A Study of the Notion of Legitimate Expectations in State Aid Recovery Proceedings: “Abandon All Hope, Ye Who Enter Here”? 'CMLR' 2008, no 5. 
19. Grespan D., Pelin A., Rossi L., Recovery of Unlawful and Incompatible Aid [in:] N. Pesaresi, K. Van de Casteele, L. Flynn, Ch. Siaterli (eds), 'EU Competition Law', Volume IV: State Aid, Book Two, Second Edition, Claeys \& Casteels, 2016.

20. Grespan D., Recovery of Unlawful and Incompatible Aid [in:] W. Mederer, N. Pesaresi, M. van Hoof (eds), 'EU Competition Law', Volume IV: State Aid, Book One, Claeys \& Casteels, 2008.

21. Holscher J., Nulsch N., Stephan J., Ten Years after Accession: State Aid in Eastern Europe, 'EStAL' 2014, no 2.

22. Jaros K., Ritter N., Pleading Legitimate Expectations in the Procedure for the Recovery of State Aid - What are the Recent Developments in Case Law and the Commission's Practice? 'EStAL' 2004, no 4.

23. Kamiński J., Rozwadowski W., Wołodkiewicz W., Prawo Rzymskie - Słownik encyklopedyczny, Wiedza Powszechna, Warszawa 1986.

24. Kędzia Z., Relacje między Europejska Konwencja Praw Człowieka a Karta Praw Podstawowych po przystapieniu Unii Europejskiej do Konwencji [in:] J. Barcz (ed.), 'Ochrona praw podstawowych w Unii Europejskiej', C.H.Beck, Warszawa 2008.

25. Kobus A., Zasada ochrony zaufania w sprawach dotyczacych windykacji pomocy publicznej, Taxpress 2008.

26. Kornobis-Romanowska D., Umocnienie statusu jednostek w UE po przystapieniu UE do EKPCz, Konsekwencje dla ustawodawcy i sq̨dów krajowych - następstwa praktyczne [in:] J. Barcz (ed.), 'Ochrona praw podstawowych w Unii Europejskiej’, C.H.Beck, Warszawa 2008.

27. Kowalik-Bańczyk K., Procedural Autonomy of Member States and the EU Rights of Defence in Antitrust Proceedings, 'YARS' 2012, vol. 5(6).

28. Lenaerts K., Gutiérrez-Fons J.A., The Constitutional Allocation of Powers and General Principles of EU Law, 'CMLR' 2010, no 6.

29. Łętowska E., Dialog i metody. Interpretacja w multicentrycznym systemie prawa (part I), 'EPS' 2008, no 11.

30. Łętowska E., Dialog i metody. Interpretacja w multicentrycznym systemie prawa (part II), 'EPS' 2008, no 12.

31. Marguery T., European Union Fundamental Rights and Member States Action in EU Criminal Law, 'Maastricht Journal' 2013, vol. 20, no 2.

32. Mik C. Europejskie prawo wspólnotowe. Zagadnienia teorii i praktyki., vol. 1, C.H.Beck, Warszawa 2000.

33. Mik C., Karta Praw Podstawowych: Wyznaczniki standardów ochronnych [in:] J. Barcz (ed.), 'Ochrona praw podstawowych w Unii Europejskiej', C.H.Beck, Warszawa 2008.

34. Mik C., Komentarz do art. 6 TUE [in:] W. Czapliński, C. Mik, 'Traktat o Unii Europejskiej. Komentarz', ABC, 2005.

35. Mik C., Parlamenty narodowe wobec zasady pomocniczości w świetle prawa i praktyki Unii Europejskiej, Wydawnictwo Sejmowe, Warszawa 2015. 
36. Mik C., Znaczenie postanowień EKPCz dla ochrony praw podstawowych jako ogólnych zasad prawa w UE [in:] J. Barcz (ed.), 'Ochrona praw podstawowych w Unii Europejskiej', C.H.Beck, Warszawa 2008.

37. Nehl H.P., 2013 Reform of EU State Aid Procedures: How to Exacerbate the Imbalance between Efficiency and Individual Protection, 'EStAL' 2014, no 2.

38. Nehl H.P., The Imperfect Procedural Status of Beneficiaries of Aid in EC State Aid Proceedings - Note on Case C-276/03 P, Scott S.A. v. Commission, 'EStAL' 2006, no 1.

39. Płachta A., Zasada ochrony praw podstawowych [in:] A. Wróbel (ed.), 'Stosowanie prawa Unii Europejskiej przez sądy', vol. I, LEX a Wolters Kluwer Business, Warszawa 2010.

40. Półtorak N., Ochrona uprawnień wynikających z prawa Unii Europejskiej $w$ postępowaniach krajowych, LEX a Wolters Kluwer Business, Warszawa 2010.

41. Quigley C., European State Aid Law and Policy. Third Edition, OxfordPortland (Oregon) 2015.

42. Raitio J., The Principle of Legal Certainty as a General Principle of EU Law [in:] U. Bernitz, J. Nergelius, C. Cardner, X. Groussot, 'General Principles of EC Law in a Process of Development: Reports from a Conference in Stockholm, Stockholm 23-24 March 2007', Kluwer Law International, 2008.

43. Rossi-Maccanico P., The Koninklijke Friesland Foods Case Law: More Legal Certainty in Legitimate Expectation, 'EStAL' 2008, no 1.

44. Rzotkiewicz M., National Identity as a General Principle of EU Law and its Impact on the Obligation to Recover State Aid, 'YARS' 2016, vol. 9(13).

45. Rzotkiewicz M., The General Principles of EU Law and Their Role in the Review of State Aid Put into Effect by Member States, 'EStAL' 2013, no 3.

46. Saavedra Pinto C., The 'Narrow' Meaning of the Legitimate Expectations Principle in State Aid Law Versus the Foreign Investor's Legitimate Expectations. A Hopeless Clash or an Opportunity for Convergence? 'EStAL' 2016, no 2.

47. Saryusz-Wolska K., Kośka K., W poszukiwaniu utraconej skuteczności. Zasada natychmiastowego i skutecznego zwrotu pomocy państwa [in:] B. Kurcz (ed.), 'Prawo i ekonomia konkurencji, Wybrane zagadnienia', LEX a Wolters Kluwer Business, Warszawa 2010.

48. Schønberg S, Legitimate Expectations in Administrative Law, Oxford University Press, 2000.

49. Sinnaeve A., Procedure Regarding Unlawful Aid [in:] M. Heidenhain (ed.), 'European State Aid Law', C.H.Beck, München 2010.

50. Sinnaeve A., State Aid Control: Objectives and Procedures [in:] S. Bilal, P. Nicolaides (eds), 'Understanding State Aid Policy in the European Community. Perspectives on Rules and Practice', Kluwer Law International, 1999.

51. Thym D., In the Name of Sovereign Statehood: A Critical Introduction to the Lisbon Judgment of the German Constitutional Court, 'CMLR' 2009, no 6. 
52. Tridimas T., The General Principles of EU Law, Second Edition, Oxford 2006.

53. Varju M., European Union Human Rights Law: The Dynamics of Interpretation and Context, Edward Elgar Publishing Limited, 2014.

54. von Bogdandy A., Schill S., Overcoming Absolute Primacy: Respect for National Identity Under the Lisbon Treaty, 'CMLR' 2011, no 5.

55. White S., Rights of the Defence in Administrative Investigations: Access to File in EC Investigations, 'Review of European Administrative Law' 2009, vol. 2, no 1.

56. Wróbel A., Źródła prawa Unii Europejskiej [in:] A. Wróbel (ed.), 'Stosowanie prawa Unii Europejskiej przez sądy', LEX a Wolters Kluwer Business, Warszawa 2010.

57. Wyrozumska A., Inkorporacja Karty Praw Podstawowych do prawa UE: Status Karty w prawie UE, zakres obowiązywania i stosowania, główne problemy interpretacyjne z uwzględnieniem stanowiska polskiego [in:] J. Barcz (ed.), 'Ochrona praw podstawowych w Unii Europejskiej’, C.H.Beck, Warszawa 2008.

58. Zenc R., Prawo do obrony we wspólnotowym prawie konkurencji [in:] C. Mik, K. Gałka (eds), 'Prawa podstawowe w prawie i praktyce Unii Europejskiej', TNOIK Toruń, 2009. 